\title{
COVID-19 AND THE TRADITIONAL CULTURE OF THE UDMURTS
}

\author{
Nikolai Anisimov \\ Department of Folkloristics \\ Estonian Literary Museum, Estonia \\ Department of Philological Studies \\ Udmurt Institute for Research in History, Language and Literature \\ UdmFRC UB RAS, Russia \\ nikolai.anisimov@folklore.ee; kyldysin@yandex.ru \\ Galina Glukhova \\ Institute of Udmurt Philology, Finno-Ugric Studies and Journalism \\ Udmurt State University, Russia \\ galant@udm.ru
}

\begin{abstract}
The article discusses the spring rites and summer prayers of the Eastern (Trans-Kama) Udmurt and the Udmurts' festivals (Bydzh'yn nunal, Akashka, Paskha, tulys kis'ton, Gurt/-en vös', and Mör vös') during the quarantine period related to COVID-19, as well as comic songs and chastushkas (ditties) on the topic of quarantine and self-isolation. It is the first attempt to describe and characterize the consequences of the global pandemic as reflected through the traditional culture of the Udmurt people. Materials used for the analysis were internet posts, data from informants, articles from district newspapers, and the observations of the authors. The presented materials allow us to speak about changes in the form of the Udmurt traditional ritual events and people's ability to adapt to a crisis situation. Self-isolation has caused concern among many villagers because of the inability to hold festivals in real time and space. A study of internet posts has shown that the Udmurts willingly share their preparations for the festivals and send greetings to each other that reflect both joyful and sad emotions. Udmurt songs and chastushkas with humorous content uploaded on websites help them to overcome the difficult situation caused by the coronavirus.
\end{abstract}

Keywords: chastushkas (ditties), comic songs, COVID-19, Internet posts, rituals and festivals, self-isolation, traditional culture, Udmurts, virtual space

The complex epidemic situation due to COVID-19 has affected the way traditional cultures practice national customs and rituals. The way national rites and customs are performed has changed significantly and in some cases these 
had to be completely abandoned (see, e.g., Coronavirus 2020; Manichkin 2020; Japanese 2020; Amelina 2020; Prange \& Zhukov 2020; Kulichenko 2020). On the other hand, they have also found ways to overcome the crisis situation through adaptation (Volodina 2020; Traditional medicine 2020; Korovina 2020).

Due to the outbreak of the coronavirus in all regions of Russia, from March 30,2020 the state decided to impose quarantine and to follow a regime of selfisolation, which meant that people had to stay at home and avoid events where groups of people gather.

It should be noted that before the events of early 2020, external factors had had a gradual impact on the traditional culture of the Udmurts. However, the conditions of quarantine and self-isolation have put the Udmurts in a difficult situation, which asks them to abandon the established customs and behavioral patterns, and to find compromises and adapt to the current reality instead.

In this study, we analyze the practice of the spring rites of the Udmurts in the context of the pandemic (the ritual cycle Bydzh'yn nunal / Bydzh'ym nunal / Bydzh'ynnal / Bydzh'ymnal ('the Great Day'); Akashka ('the Feast of the Plow'), which marks the beginning of the year according to the national calendar and the beginning of spring field work, ${ }^{2}$ Orthodox Easter, and tulys kis'ton 'spring commemorations') as well as the summer prayers of the Udmurts of Bashkortostan. The choice is justified by the fact that these particular rites and festivals coincided with the quarantine in Russia. The article also discusses how the phenomenon of writing songs and chastushkas devoted to the theme of the coronavirus and self-isolation is a creative reaction of a society to extraordinary life events.

The nationwide COVID-19 crisis has caused some informants' extreme anxiety, as it is possible that the extinction of traditional rituals may cause people to completely abandon them in the following years. As the informants noted, the collective participation and consolidation of the kin and community were threatened in favor of individualism, as the mentioned festivals imply the participation of a large number of people visiting the houses of relatives and holy places as well as communal discussions and meals. For instance, the Southern Udmurts' ritual visits to their relatives' houses in the patrilineal group vös'nerge ('the ceremonial guesthood by the family'), performed on the day of the Bydzh'yn nunal celebration, have gradually faded in recent years. Locally, some families separated from the lineage group and stopped participating in vös'nerge. In several ethnographic groups, the ritual visits during the spring memorials - tulys kis'ton - had completely disappeared by the beginning of the twenty-first century. This practice can be found only in separate local traditions or in single families. 
During the pandemic, mass gatherings of people and visits to cemeteries were also prohibited, as was reported in the news or via public information campaigns. In some areas, members of police teams that monitored quarantine adherence were at the entrance to the cemetery. Villagers also had to refrain from visiting sacred places in groups and participating in public ceremonies. At the same time, people have become quite active in the internet space, primarily in social networks: for example, on Vkontakte, Facebook, Odnoklassniki, and Instagram.

Thus, the authors of this article chose to rely actively on online methods and to adopt virtual ethnographic approaches, as it was too complicated to make full-fledged fieldwork. A whole range of published studies (e.g., Markham 2004 [1997]; Hine 2000; Sergeyeva 2010) about research in the digital milieu allowed us to turn towards this kind of experience. In this regard, the main sources of research were various posts by the Udmurts on social networks concerning our topic, online interviews and communication with the Udmurts from different local groups, and the personal observations of the authors.

It should be noted that today the Internet has significantly influenced the modern life not only of city-dwellers, but also of villagers, due to its availability and its increasing use in daily life. The quarantine of the rural population has led to all live public festivals and rituals being moved to the virtual space. In order to diversify the leisure activities of the residents, rural cultural centers, like other cultural institutions, one of the main tasks of which is to hold events with mass gatherings of people, also found a new format for the pandemic: for example, videos made by specialists of cultural institutions in the form of various actions, flash mobs, online concerts, etc. As a result, on the one hand, people are physically isolated, but, on the other hand, the virtual world has become a tool to unite people from different strata and professions.

In some cases, at the request of the informants, information about the source is anonymized. In other cases, informants agreed to have their name published.

\section{TRADITIONAL UDMURT CULTURE ON THE INTERNET AND IN DAILY LIFE}

The internet posts studied can be conventionally divided into several categories: preparation for the festival, the festival itself, ritual dishes, greetings, and information about the rite. According to the available internet materials, it appears clearly that some Udmurt Christians use both Christian and folk symbols and terminology for rituals in their posts; for others who profess Orthodoxy more 
actively, pre-Christian elements are rare or absent. The practitioners of traditional Udmurt beliefs do not use Christian symbols. The posts were published in both Udmurt and Russian.

Below we briefly review each thematic block.

\section{Preparing for the festival}

Since the quarantine of the population has given people the opportunity to spend more time at home and, in particular, on the Internet, people began to post on various social networks how they prepared for the festival. Most people posted photographs of their festive meals and laid table with a text message about their readiness for the rite (Example 1). They also shared recipes for cakes and posted images of colored or decorated eggs. One post contained information about the choice of attire for the upcoming rite of Bydzh'ym nunal (Example 2). An Eastern Udmurt posted on Instagram about the custom of putting on new clothes and leaving gifts and colored eggs for children on the windowsill, which were allegedly left by the character Tód'y tush babay ('White-Bearded Grandfather') on the Great Day (Example 3). In addition, the Bagrash-Bigra municipality in Malaya Purga District, Udmurtia, mobilized people on Easter Eve with the hashtag \#окнаПасхи (Easter windows), which encouraged the audience to put a burning icon lamp on the windowsill at midnight and, if desired, post photographs on Vkontakte with this hashtag (Example 4). As noted by the

Ольга Перевозчикова

18 апр в 21:35

Христос воскресе! Христос воскресе! Христос воскресе! Великтэмлы дась))) Нырысьсэ пыжи куличъёс)))

К Пасхе готова))) Первый раз пекла куличи)))

\#Пасха2020
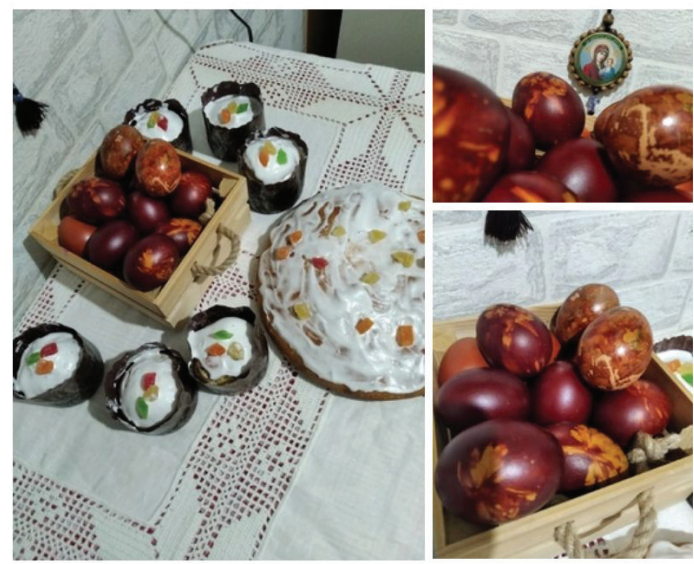

organizers, the purpose of this mobilization was to give people the opportunity to share Easter joy with others. But it is clear from the general text that uniting people with one action is an attempt to relieve tension. Note that Bagrash-Bigra village was closed in April for a sixteen-day quarantine due to a local resident having caught COVID-19.

Example 1. Source: https://vk.com/ feed? $w=$ wall62160647 7686, last accessed on 1 December 2020. 
Дорын умой, чуказе Быдз:ым нунал понна кыче меда дэремме дисялом ай малпай но. Кутски бугыръяськыны шифанерын, а отын...коня вылэм cooc( может трос но овол дыр кин ке понна). Нош тиляд вань а удмурт дэремды но коня, мон чотай али, но мынам потиз 13. Весь уг на тыры ко:ты, адямиослэсь адзисько, яке басма чеберзэ син азям йо:те ке, одно вурытэме потэ. Разбирала шкаф и оказывается у меня столько( а может и нет) национальных удмуртских платьев. А мне хочется ещё.
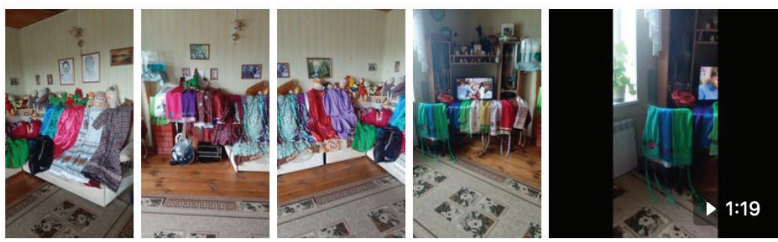

Example 2. Source: https://vk.com/feed?w=wall78392984_1912, last accessed on 1 December 2020.

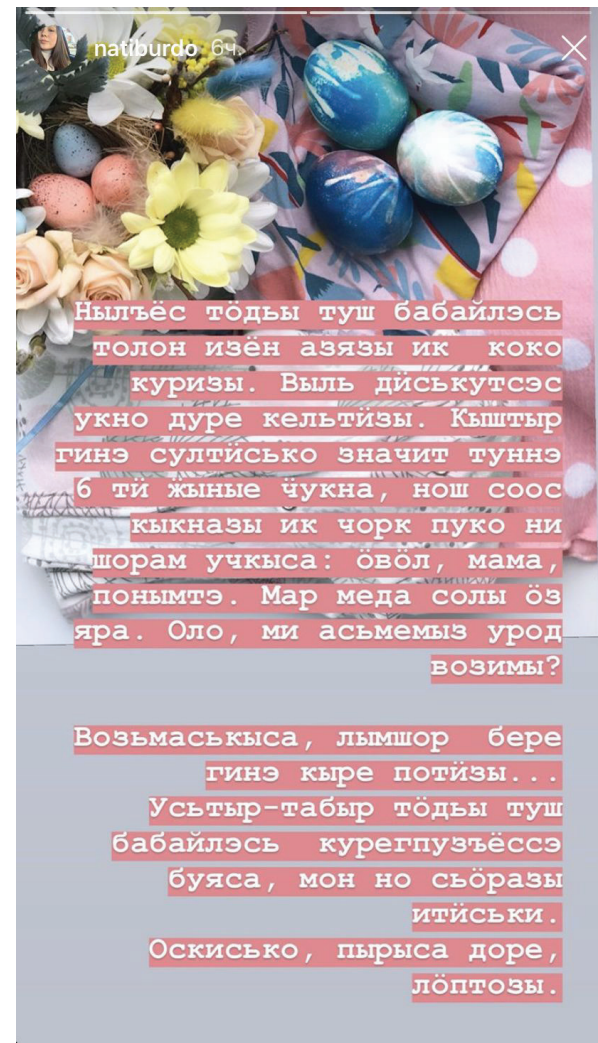

Example 3. Source: https: / / instagram.com / natiburdo?igshid=vakfekw744bk, last accessed on 1 December 2020.

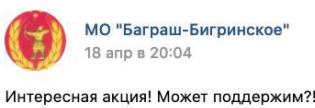

$\checkmark$ В нынешнем году из-за пандемии коронавирусной инфекции миллионы верующих вынуждены встречать Пасху дома. Люди напуганы, но мы можем исправить ситуацию. Давайте сообщим миру весть, побеждающую страх: Христос воскресе!

ح Сегодня в полночь зажгите масляную или неугасимую лампаду и поставьте ее на подоконник примерно на один час. Можете сфотографировать ее, а затем разместить снимок в социальных сетях, сопроводив хештегом \#окнаПасхи.

$\checkmark$ Делитесь друг с другом пасхальной радостью. Пусть все знают, что там, где Бог, всегда есть место надежде. В Евангелии сказано: «И свет во тьме светит, и тьма не объяла его».

Соблюдайте меры пожарной безопасности. Не размещайте лампады вблизи штор и легковоспламеняющихся веществ и предметов. Исключите доступ детей и домашних животных к источникам открытого огня. Не оставляйте зажженные лампады без присмотра.

Друзья, акция «Окна Пасхи» - не замена богослужения. Она не заменит пасхальный крестный ход и церковные Таинства. Цель этой акции - дать людям возможность поделиться с окружающими пасхальной радостью.

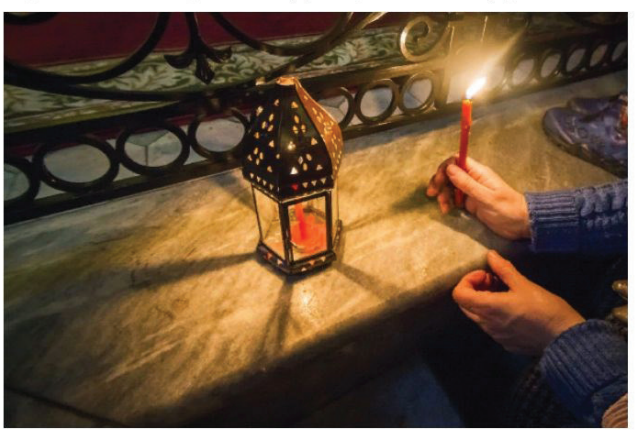

Example 4. Source: https: / /vk.com/mobagrash bigra?w=wall-165541235_4326, last accessed on 1 December 2020. 


\section{Holding the festival}

As the materials show, people often shared how they celebrated the festival at home. Irina Samigulova shared information about how she performed the rite of the Great Day, offered holiday greetings, and attached photographs of 2020 in her posts (Example 5). It is noteworthy that Anatoly Galikhanov, an Udmurt sacrificial priest from Altaevo village, Burayevo District, Bashkiria, immediately reacted to this post and tried to explain the rules of behavior on this day and the observance of the ritual via his comments. In particular, the priest writes that on Bydzh'yn nunal, you must bring water from the spring, using a shoulder yoke resting only on your right shoulder, and in no case should this water be put on the ground. Alcohol can be consumed only in the afternoon, after the family prayer and a taste of the consecrated porridge. Instagram user Valera Sabanchin from Malaya Balzuga village in the Tatyshly District, Bashkiria, posted a photograph of his father's prayer address with his son with the hashtag \#нашитрадиции (our traditions) (Example 6). In order for the festival activities during the quarantine period not to get out of control, some representatives of district organizations had to participate in raids. As an example, we can mention the post of Natalia Antonova, head of the Department of Culture of the Alnashi District, Udmurtia (Example 7). Apparently, it was not possible to maintain quarantine measures in all villages. According to another VKontakte post, children participated in the collection of painted eggs and Easter gifts, as the tradition had an important intergenerational meaning for the users (Example 8). In the Vkontakte group of the Udmurt-language newspaper of the Kukmor District of Tatarstan, Vamysh (Step), an anonymous survey about the ritual collection of eggs was conducted, which contained one question “Tunne nylpiosty potizy-a kuregpuz bich'any?” ('Did your children go out to collect chicken eggs today?') with three response options: "potizy buskel'e" ('went to the neighbors'), “öz pote” ('didn't go out'), "bydes gurtez ortch'izy” ('went around the whole village'). The results of the survey were as follows: 22.5 percent (9 people) went to their neighbors, 72.5 percent (29 people) did not participate in egg collection, and only 5 percent ( 2 people) went around the whole village. In comments to the survey, Vladimir Zhukov said that despite the prohibition of officials, he and his son went to the neighbors for eggs, which caused disapproval of some users. Natalia Matveeva, a resident of Varkled-Bodya village in the Agryz District of Tatarstan, published on her Vkontakte page a video greeting on Bydzh'yn nunal and performed the ritual chants in honor of the Akashka festival (akashka gur) with her mother. During the expedition of 2017, Nikolai Anisimov recorded the performance of this chant during the feast with a group of relatives in the patrilineal group (see Toulouze \& Anisimov 2018: 81). In Udmurt culture, the performance of a ritual chant or a part of it during 
the ritual is important as a guarantee of the success of sacred actions and for structuring the mystical order of the world. This is probably why, despite the failure to perform the traditional scenario of the rite, the performance of the ritual chant served as a symbol of a special day and its completion.

Example 5. Source: https://vk.com/ feed?w=wall22919365_12005, last accessed on 1 December 2020.

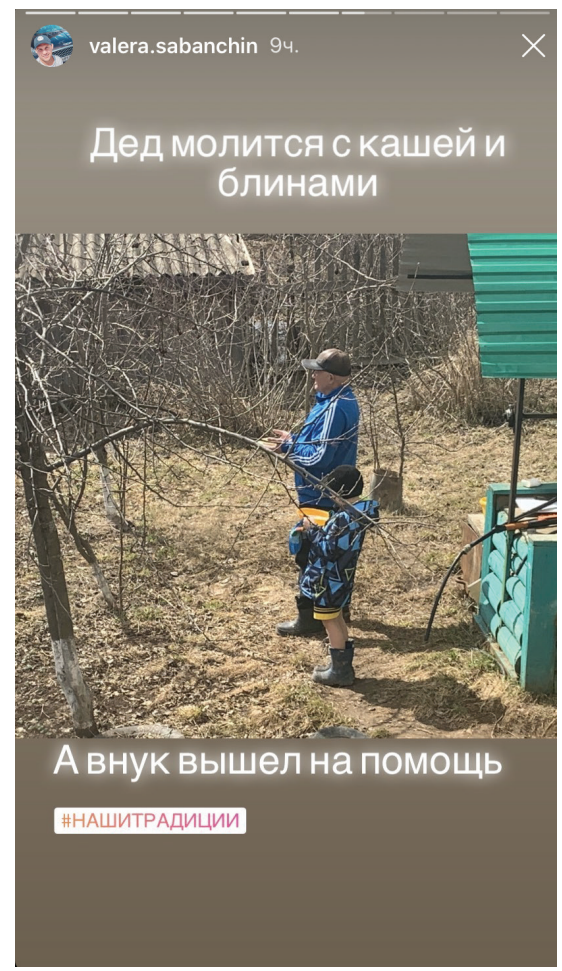

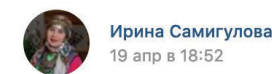

Сегодня у закамских удмуртов «Быдӟынал» (Великий день), совпадающий по срокам с православной Пасхой. Заранее иду за родниковой водой.Ведь и каша и чай должны быть приготовлены на родниковой воде. В обед начинаю варить ритуальную кашу на мясном бульоне. После обеда приготовления

заканчиваются, и на стол стелю белую скатерть, кладу специально испеченный в этот день хлеб, ставлю солонку с солью, миску крашеных яиц, кумышку, табани и кашу.

Счастья, мира, благополучия, здоровья любимым детям и семье , близким и друзьям, родственникам, пусть у всех все будет хорошо!

Мира и добра Всем!

Быдӟынал праздникен ваньдэс но!

Сюлмысь куриськыса жук сиимы.
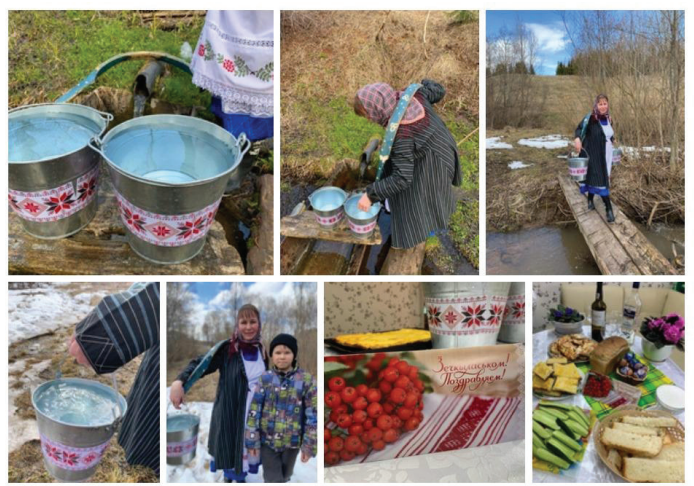

Example 6. Source: https://instagram.com/ valera.sabanchin?igshid=1prluiaho9jcu, last accessed on 1 December 2020. 
Недавно пришла домой с рейда (в рамках карантина). Замерзла Є. Теперь можно и побаловать себя праздничным обедом! :-: Христос воскресе всем! Будьте здоровы! Берегите друг друга!

\#СветлаяПасха

\#Оставайтесьдома

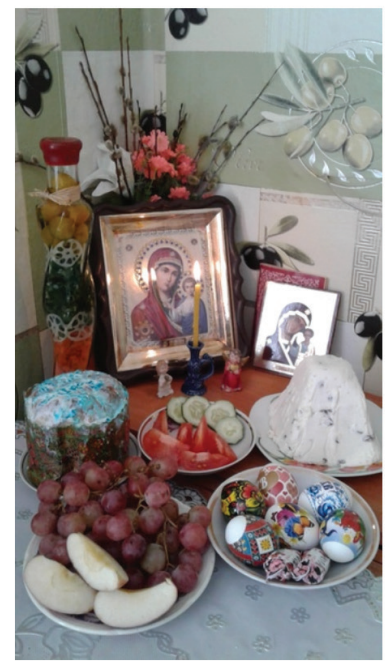

Example 7. Source: https://vk.com /feed?w=wall187813714_2144, last accessed on 1 December 2020.

А вот и наша Пасха! Когда то мы тоже ходили по домам и было очень весело и круто,в детстве очень ждали этот праздник, а теперь наши дети. И конечно же как без маминых любимых ватрушек с творогом $\Leftrightarrow$
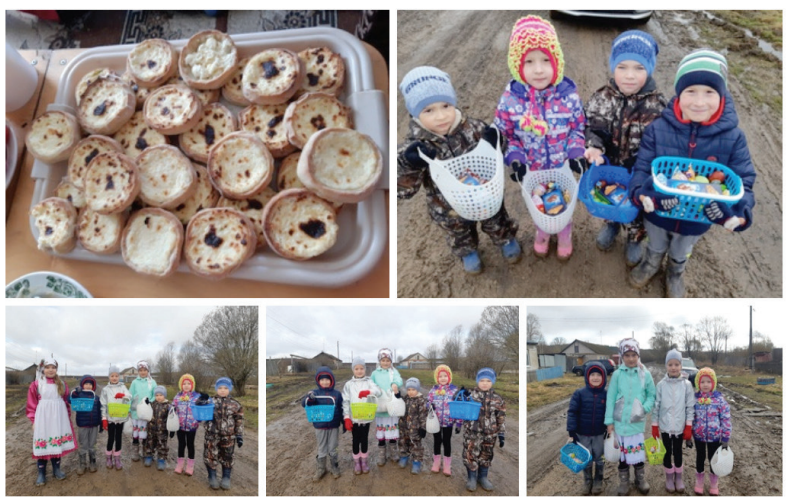

Example 8. Source: https://vk.com/feed?w=wall142962886_1592, last accessed on 1 December 2020. 


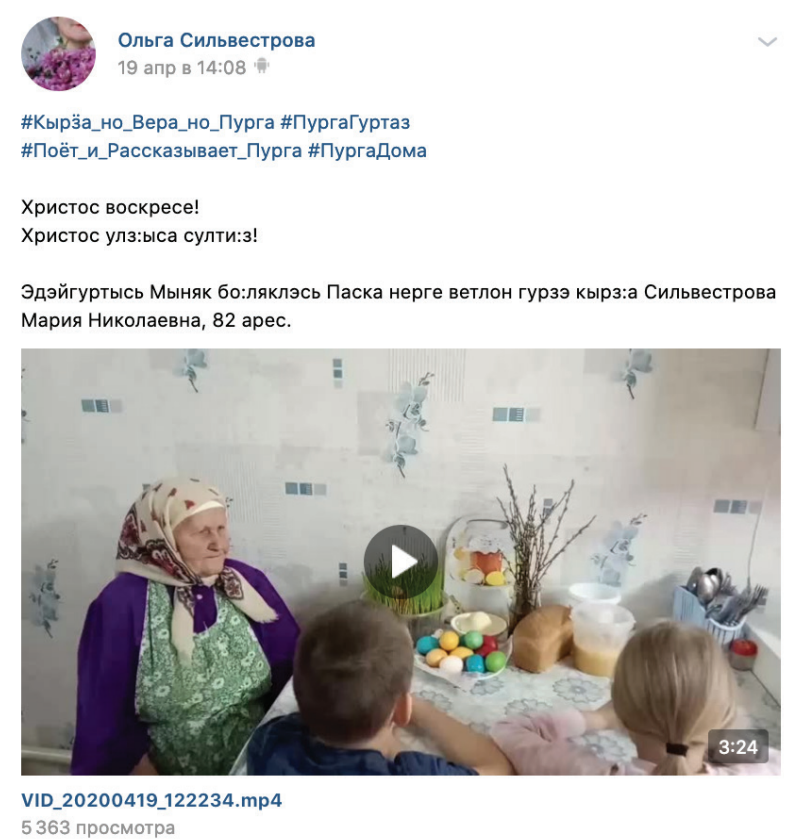

Example 9. Source: https://vk.com / id161457323?w=wall161457323_550, last accessed on 1 December 2020.

Another example is the video on the Vkontakte page of a resident of BobyaUcha village of the Malaya Purga District, Udmurtia, Olga Sil'vestrova, in which her mother-in-law Maria Nikolaevna Sil'vestrova (born in 1938) performs Pas'ka n'erge vetlon gur (the visitation chant [of houses of the kin] on Easter) of the Mynyak bölyak (Example 9). The name of the chant clearly indicates its functional meaning. Perhaps that is why the daughter-in-law asks her motherin-law to perform this ritual chant during the quarantine on Easter Day. The video shows an elderly woman singing a song at the table with children, which symbolically already serves as a festival feast. Since this type of tune is rarely performed nowadays, and is disappearing, below are the lyrics of the song:

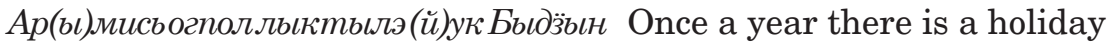
нунал юондыр, of the Great Day,

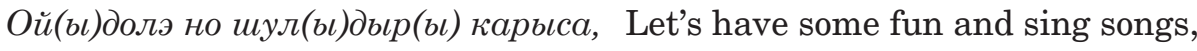
кьр(ь)ӟаса пуколе. sit.

Ой(ъь)долэ но шул(ь)дьıр(ьı) карьса, Let's have some fun and sing songs, кыр(ь)ӟаса пукоме. sit.
} 
“Осто” гьнэ шу(в)илиь ке, Инь(ьь) мар кабьл(ьь) мед кароз.

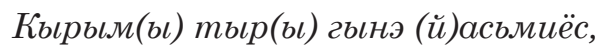
мусо гынэ кайёсы.

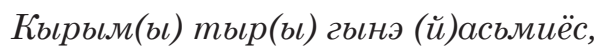
мусо гынэ кайёсы.

Кизььллэлною-няньёсльссӥзььлозьлед Let our sown seeds ripen until fall, кисьлалоз,

Уэнасьгынэадялиёсль тазальљзэслед For working people,

сётоз.

Ужасьгынэадямиёсль тазалькзэслед сётоз.

Ой, тау улэ, тау улэ (й)ук, мусо гьннэ кайёсьи,

Талэсь но бон(ьь) бадӥьнь(ь)ёссэ шӧдьтыса но(й) улэлэ.

Талэсь но бон(ьь) бадӥьнь(ь)ёссэ шӧдьтыса но улэлэ.

Тау карьса (й)ум(ьь) кошкиське, нош но вуольь (й)али,

Тау карьса (й)ум(ьь) кошкиське, нош но вуоль али.
As soon as we say "Oste", let

Inmar ${ }^{5}$ hear.

There are few of us - just a handful, my loves.

There are few of us - just a handful, my loves.

let [God] give health.

For working people,

let [God] give health.

Oh, thank you, thank you, my dear,

Finding more than this [wealth] live.

Finding more than this [wealth] live.

Thanking don't leave, again, come again.

Thanking don't leave, again, come again.

(Source: https://vk.com/id161457323?w=wall161457323_550, last accessed on 1 December 2020)

The ethnomarathon Daur shykys ('Chest of the Century'), dedicated to the 100th anniversary of the statehood of Udmurtia and marked by the hashtags of \#культураУдлуртии (culture of Udmurtia), \#этольє (It's us), \#АлнашскийРДК (Alnashi community center), \#сидилдола (stay at home), and \#100летУдмуртия (100 уеars of Udmurtia), was announced in the group Alnashi RDK. The aim of the project was "to increase interest in the traditions and customs of the Udmurt people and the preservation of intangible cultural heritage" ${ }^{6}$ The first category of the ethnomarathon was announced as Anai-atai gur"esmy ('Chants of our fathers-mothers'), where it was suggested to record ritual chants of Bydzh'yn nunal, Akashka, and vös'nerge festivals as they exist in the family, clan or village. Ten home videos of ritual tunes were attached to the post. Most of the participants were natives of the Alnashi District of Udmurtia, and one video was from Vyazovka village of the Tatyshly District of Bashkiria. 
During the writing of the article, informants also reported that in one of the Udmurt settlements of Tatarstan, despite the quarantine, the annual tradition of the spring rites was not interrupted. The rites were held according to the established canons and with the participation of almost all the villagers. Due to the quarantine, only those former villagers who went to live in other districts and towns and are no longer permanent residents of the village could not attend the ceremonies. The decision to hold it was made by the majority of the villagers. As one informant jokingly shared: "We are doing disinfection for the coronavirus" (anonymous, oral message, 2020), meaning they were consuming alcohol. It should be noted that here the tradition was never interrupted, even during the years of Soviet atheism and religious persecution. Moreover, scientists of the late nineteenth and early twentieth centuries noted the zealous observance and preservation of customs by these Udmurts. On this basis, it is possible to understand their choice in favor of their faith and traditions, even during the global pandemic of the early twenty-first century.

Orthodox Udmurts also found themselves in difficult circumstances. Due to the coronavirus, parishioners and pilgrims were forbidden to visit churches (Example 10). Instead, representatives of the Russian Orthodox Church invited them to watch a live broadcast of the divine service. In addition, the dangerous global COVID-19 situation has become an occasion for increasing anxiety and worry about the descent of the Holy Fire in Jerusalem. As stated, if this fire does not descend to Earth, it will mean the beginning of the end of time. Almost all the media, bloggers and Internet users were talking about the possibility of the end of the world, which created even more panic and anxiety among the population. However, divine services were held in churches, but only a small number of people participated: priests, singers, helpers. So, in the Udmurt parish of Izhevsk, singers could visit the temple to participate in divine services (oral report by Irina Pchelovodova, 2020). Thus, services in churches were held and even broadcast on television and social networks. For example, Galina Shushakova's post indicates that holding the Udmurt divine service is important, for which she thanks Father Pavel and Father Mikhail, as well as the singers (Example 11). During the Easter service, some stood at home in front of the TV, lit candles and prayed as if they were present in the temple during the service. Others consulted with priests and, depending on their circumstances, prayed alone or with their families. Many asked for protection from disaster in their prayers. However, these forced conditions, as noted by informants, did not bring much joy and created a sense of solemnity in the celebration of Easter. Perhaps this was due to, for example, the abolition of collective participation in the festival, the lack of spiritual unity during the important event, and the inability to be present at church as a place of worship. Pre-Easter and post-Easter days are 
considered great days in Orthodoxy, so the divine services on these days are special for parishioners. In this regard, because of the prohibition of going to church, many Udmurts tried to find ways to transmit notes about health and about relief from stress to be read by priests during the liturgy: for example, those who knew Father Pavel personally called him directly; others contacted him through the singers. As a whole, the peculiarities of the Udmurt Orthodox religious services are very close to other ceremonial practices in other regions of Russia (see, e.g., Soldatov 2020; Kuznetsova 2020; Radchenko 2020).

The special conditions also included the conclusion of the tulys kis'ton (spring commemorations), which are usually held a week after the Bydzh'ym nunal celebration. It should be noted that the spring commemoration also includes a visit to the cemetery on May 9. Initially, this day was dedicated to the memory of those who died during the Great Patriotic War. It later became the day of commemoration of all the dead. In the case of the Easter celebration, people were not allowed to hold a commemoration ceremony with a large number of attendants or to visit the cemetery. In this regard, in some traditions in which relatives' homes are still visited, the spring commemorations were held with the participation of the closest relatives only (Example 12).

МоЯ УДМУРТИЯ. ИВОРъЁС

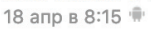

1.. Шаерамы черкъёсын вӧсяськисьёсты доразы пукыны куро.

17-тй оштолэзьысен коронавирус инфекциез алон вылысь черкъёсы но храмъёсы пыраны уг яра. Службаос калыктэк ортчылозы.

\#МынамУдмуртие телерадиокомпания туннэ 23 час 30 минутысен мейак

эфирын возьматоз Ижкарысь Михайло - Архангеллэн кафедральной

соборысьтыз праздниклы сйзем службаез.

Учкыны луоз Удмуртия телеканалысь но myudm.ru сайтысь. Озьы ик

чӧлскетъёс луозы мерлыко герӟетъёсмы пыр.

Уте асьтэды, матысь адямиостэс! Пуке дорады!

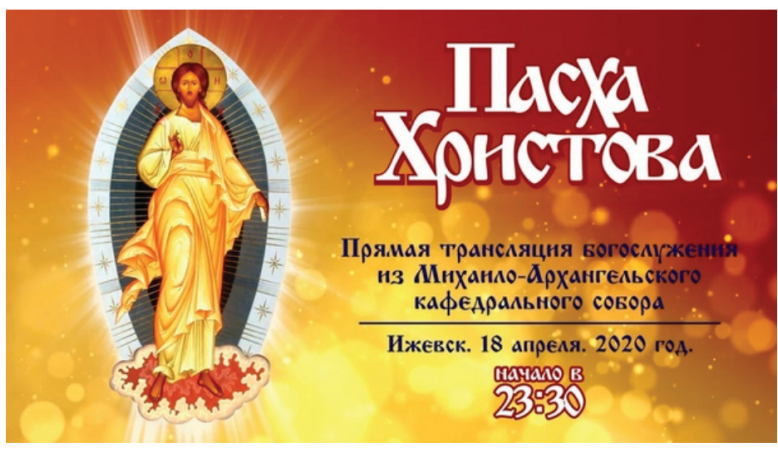

Example 10. Source: $h t t p s: / / v k . c o m / m y u d m ?$ ?w=wall-25185834_24314, last accessed on 1 December 2020. 
Христос кулэмысь улз:ыса султи:з!Тау, Инмарлы, удмурт служба мынэ! Тау, отец Павеллы, отец Михаиллы, чирди:сьёслы!!! Тазалык Ти:ледлы씨 !

Удмурт черк/Удмуртские службы/Udmurt church 18 апр 2020 в 23:19 숭

Христос кулэмысь улз:ыса султи:з! Христос Воскресе!
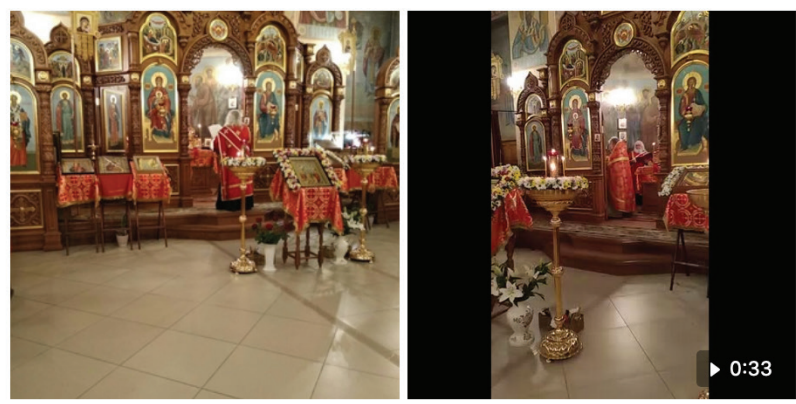

Example 11. Source: https://vk.com/feed?w=wall55651469_1753, last accessed on 1 December 2020.

\section{Кисьтон.}

HБ, 2020.

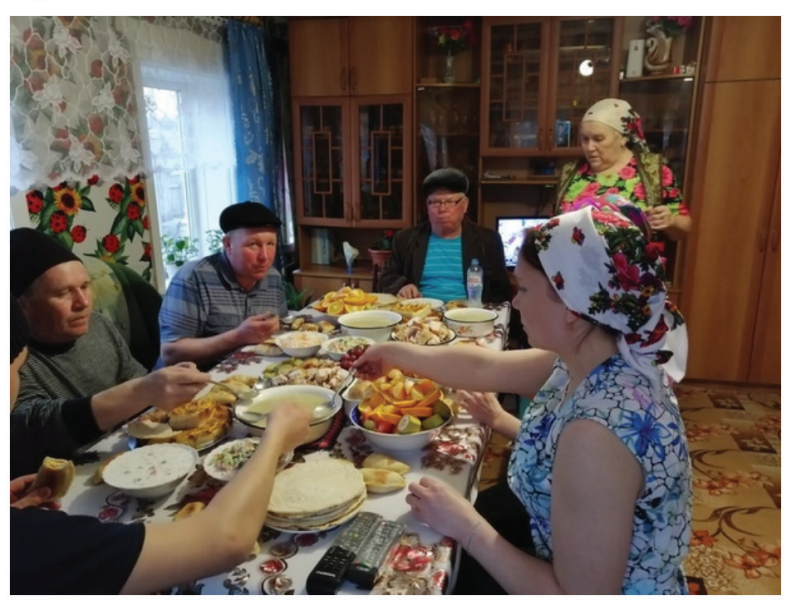

Example 12. Source: https://vk.com/shaislamova15?w=wall160459663_7557, last accessed on 1 December 2020. 
In another case, the commemorations were held within the family circle. According to informants, a certain paradox arose in one of the Bashkortostan districts: despite the mentioned prohibitions, it was ordered to do Saturday community work to clean up local cemeteries. Part of the population followed self-isolation measures, held a commemoration ceremony in a narrow family circle and did not visit the graves of their dead. But according to informants, most people still took part in the traditional visit to the cemetery. "The cemetery was like Sabantuy ${ }^{7}$," said one of the informants (anonymous, oral report, 2020). In some cases, safety precautions and social distancing were disregarded. For example, according to tradition, when remembering their dead, many did not wear masks and drank from the same glass (anonymous, oral message, 2020). Also, at the spring commemorations and on May 9, villagers who had left for other districts and cities came to pay respects to their deceased ancestors. It should be noted that in some areas (e.g. Izhevsk) by this time there were no strong restrictions or special warnings about visiting cemeteries, but the risk of infection remained. When remembering their dead, people also asked for their protection from the spreading pandemic. Moreover, the informants reported that in one district of Udmurtia, a large number of people gathered for a funeral to pay their respects to a deceased woman in one case and a deceased man in another. At the same time, none of the funeral participants felt in danger of getting seriously ill. Tradition was stronger than the newly announced rules of behavior. These examples show a special attitude towards deceased ancestors and a steady belief in their help and protection. As our informants note, spring commemorations and May 9 are considered the festival of the dead who wait for their living relatives. It is believed that not observing the simplest ritual actions (not visiting the graves of the deceased relatives or not remembering them) can lead to various problems.

\section{Greetings}

Many posts were dedicated to holiday greetings in both the Udmurt and Russian languages, sometimes with various hashtags reflecting the message content: for example, \#будӟьннал, \#великтэл, \#пасха (all meaning Easter). Some contained a short greeting, while others were expanded with various wishes, often protection and keeping disease at bay. Here are some examples:

Будӟьналэн!!! Та питрес курегпуз кадь, тыр но ӥьж-ӥьж мед луоз улондьц!! Вань шуг секьтъёс палэнтӥ мед ортчозы коркаостэс.

Happy Easter to You!!! Let your life be as healthy and full as this festive egg!!! Let all misfortunes and troubles pass you by! (Example 13) 
Example 13. Source: https: / /vk.com/ shonerpaul? $w=$ wall44496167_8688, last accessed on 1 December 2020.

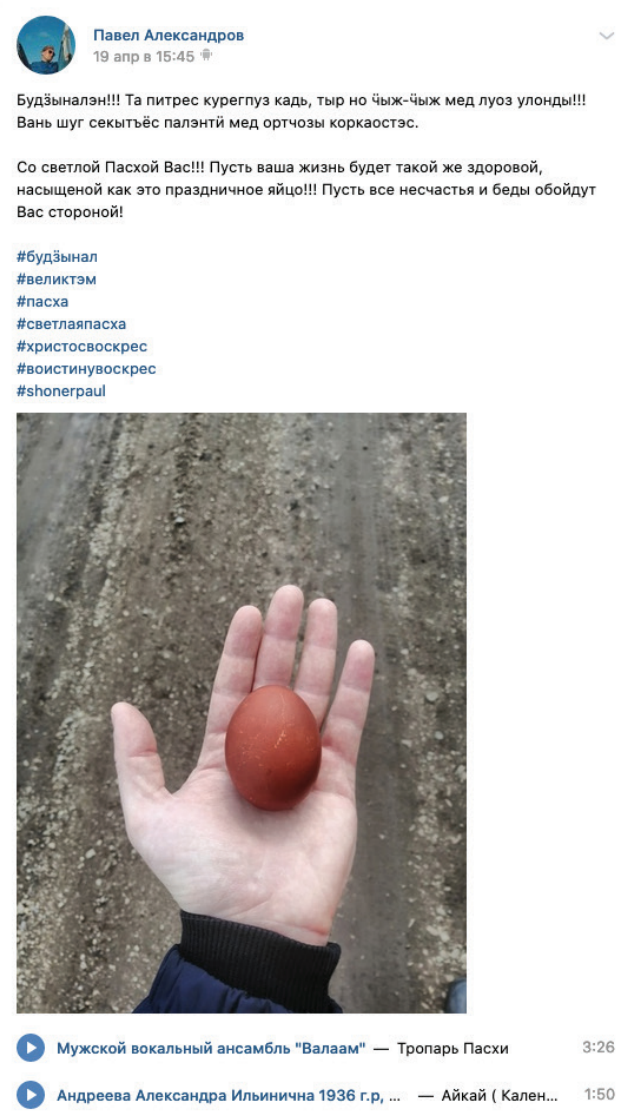

ХРИСТОС УЛӞЫСА СУЛТЭМ! ЗЭМ НО УЛӞЫСА СУЛТЭМ! ЮГЫТ АКАШКА НУНАЛЭН ТИЛЕДЫЗ! АРМЫ КАПЧИЕН, ШУЛДЫР УЖЪЁСЫН МЕД ОРТЧОЗ! ТАЗАЛЫК, ТУПАСА УЛОН, ШУДБУР, КАНЬЫЛЛЫК МЕД ЛУОЗ КОТЬКУД КОРКАН!

Christ is risen! Indeed he is risen! Happy Akashka day to you! Let our year pass easily with joyful works! Let health, sympathy, happiness, and ease be in every home! ${ }^{8}$

Ваньдэсты Быцзыли Паскаен! Котькуд сельяе мед пьюроз Яратон, Тазальк, Шудбур, вань висенъес палэнэти мед кошкозы! Чагыр инбал но яркьт шундьк котьку мед луоз!

Happy Easter to all! Let Love, Health, and Happiness come to every family, let all diseases be avoided! Let there always be a blue sky and a bright sun! ${ }^{9}$ 


\section{(2) моя УдмуРтия. ИвоРъЁс \\ 19 апр в 10:08}

Ӟечкыласьком Быдӟым нуналэн!

Великтэмен! Акашкаен! Быдӟынналэн!

Сюлэмъёсмес мед шунтоз зечезлы оскон!

Уте асьтэды, котырысь адямиостэс, эн ыштэ саклыктэс!

Тазалыко луэ!!!

\#МынамУдмуртие \#МояУдмуртия \#Иворъёс

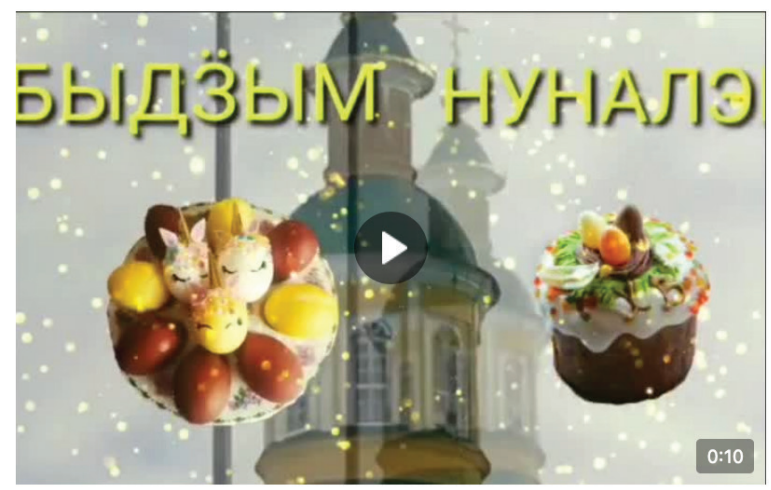

04-19-10.33.48

2239 просмотров

Example 14. Source: https: / /vk.com / myudm? w=wall-25185834_24321, last accessed on 1 December 2020.

Ольга Замараева-Антипина

19 апр в 6:41 iํ

Как жаль, что мой кулич не подарить, яйцо по интернету не отправить... Осталось лишь «ХРИСТОС ВОСКРЕС!» сказать и луч тепла в душе у вас оставить!!!

Со светлым праздником Пасхи, друзья! $/$.

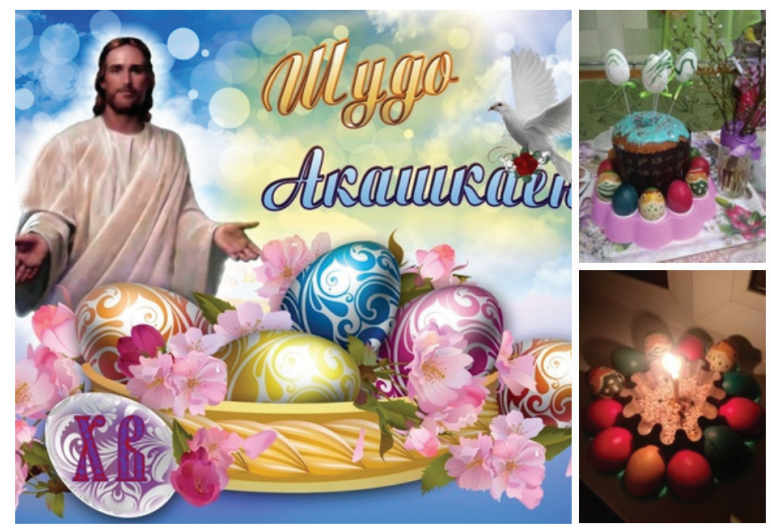

Example 15. Source: $h$ ttps: / / vk.com / id455362247? w=wall455362247_1418, last accessed on 1 December 2020. 
Ӟечкыласьком Быдйым нуналэн! Великтэмен! Акашкаен! Быцдйынналэн! Сюлэлгёслес мед шунтоз ӟечезлы оскон! Уте асьтэды, котырысь адялиостэс, эн ыцтэ саклыктэс! Тазалыюко луэ!!!

Greetings on the Great Day! Happy Great Day! With Akashka! Happy Great Day! Let our hearts be warmed by faith in the good! Take care of yourself and your loved ones, do not lose vigilance! Be healthy! (Example 14)

Как жаль, что мой кулич не подарить, яйцо по интернету не отправить... Осталось лишь “ХРИСТОС ВОСКРЕС!” сказать и луч тепла в душе у вас оставить!!! Со светльмм праздником Пасхи, друзья!

What a pity that my cake is not a gift, an egg on the Internet is not sent... It remains only to say, 'CHRIST HAS RISEN!' and leave a ray of warmth in your soul!!! Happy Easter holiday, friends! (Example 15)

Югыт Пасхаен! Быљзыннналэн! Ваньмыз умой мед луоз! Happy Easter! Happy Great Day! Let everything be fine! $!^{10}$

Ӟечкыласьком Акашкаен! Congratulations on Akashka!

Чылкыт малпанъёсын

Тырмытом улонмес.

Ӟечезльь осконэн

Юнлатол сюлэмлес

With pure thoughts we'll fill our lives.

With faith in the good

we'll strengthen our hearts

(Example 16)

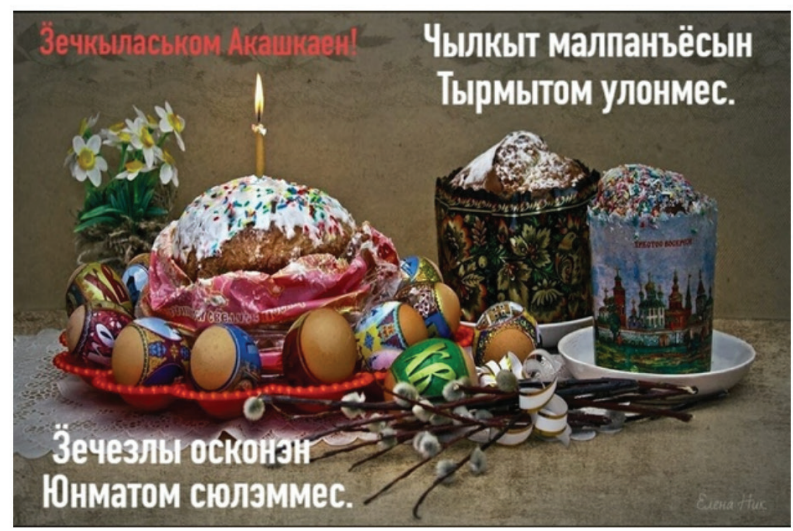

Example 16. https:/ / vk.com/feed? $\mathrm{w}=$ wall128050325_1070, last accessed on 1 December 2020. 
On his Vkontakte wall, the Udmurt priest Anatoly Galikhanov even published prayers. One prayer is for the kin, to which a photograph of a summer ceremony in the sacred grove is attached. The other is in honor of Bydzh'ynnal festival to which a photograph of taban ${ }^{11}$ (as an important ritual dish) is attached, and an audio recording of a prayer by the sacrificial priest Islam Armanshin, preserved since 1973:

ШУДО БУРО МЕД ЛУОЗ БЫДӞЫНАЛМЫ!!! Тани нош улон сюрэслэсьлэсь ог ӟоззэ ортчил. Куриськеләёсль Инлар Бабыкайль доры мед вуоз. Куриськелмэс кабыл мед кароз, мед басьтоз. Олин! Happy be our Great Day! Here again, one period of the road of life has passed. May our prayers reach our elder Inmar. Let him hear and accept our prayers. Amen! $!^{12}$

\section{ВЫЖЫ ПОННА КУРИСЬКОН}

Югынт но мусо Инларе-Кьлчинэ, Азьпалан улонын милелль Тон юрттыь!

Выжылиес шудбурен, зечлькен юнлиатьь.

Кутскел ужъёслес пулозяз вуттыны Кужылидэ но визьдэ сёты Тон, Инлиаре! you, my Inmar!

Янгыш сюреслэсь утьы Тон выжылмес, From a wrong path save you our kin, Азвесь кенерен котырты дыцлиолэсь. With a silver fence surround from

Через”, кыльдэез” тузонэн Тон пазьгы, The disease, infection you turn to dust, Андан-азвесен тазальк Тон сётьи, Малык киыныд вешалля нылпилес, Югыт Шундьен шунты та улонлес! Ванен но бурен, тьр шудэн но зечен, Гид тырос пудоен, бакча ельщен, Нянен но вӧен, мушен-чечыен, Ньлььн но пиен, семьяен, туганэн,

Калькен огкьльсь улондэ сёть Тон, Инлмаре!

Кабыл но басьты курелмес милесьтыли, Югыт но мусо, Инларе-Кылчинэ! олин! Олин! Олин! 13 the enemy.

\section{PRAYER FOR THE KIN}

My bright and sweet Creator Inmar, In the future, you will help us!

Strengthen our kin with happiness and kindness.

To complete the work started Give us strength and intelligence, give you [like] steel-silver health, Smooth our children with a gentle hand, Warm our life with the bright Sun! Prosperity, full of happiness and good, Full of cattle and vegetables, Bread and butter, honeybees, To daughters and sons, family, relatives,

In harmony with the people give you life, my Inmar!

Accept our prayers, Bright and sweet, my Inmar-Kylchin ${ }^{14}$ ! Amen! Amen! Amen! 
On his Vkontakte wall, Valery Nuriakhmetov posted with greetings a photograph from the family archive, where his children show painted chicken eggs (Example 17). This example shows how people turn towards the family album as the guardian of family history, and reveals the virtual call upon the family, as well as publicizes the importance of the emotional unity of relatives during festivals, which they were deprived of due to self-isolation.

Public organizations and public figures post their greetings and focus on the need to stay in self-isolation and follow precautionary measures. Special importance in such posts is given to illustrations and photographs that highlight a festive table, decorations, and ritual dishes, various attributes that symbolize the festival (e.g., the willow, candles, flowers, or new clothes for children of the Eastern Udmurts (Example 18)).

* БыдӞыМНУНАЛЭН! * Фотография из семейного альбома Нуриахметовых.

На фото: Руслан, Арина, Эльза Нуриахметовы и Дмитрий, Иван, Ирина и Алексей Тимирзяновы. А Валерий Нуриахметов (фотограф), как всегда, по эту сторону...

«Есть праздники, которые имеют свой запах. На Пасху, Троицу и на Рождество в воздухе пахнет чем-то особенным. Даже неверующие любят эти праздники. Мой брат, например, толкует, что Бога нет, а на Пасху первый бежит к заутрене..."

(А. П. Чехов, рассказ «На пути»).

https://oshmes.rbsmi.ru/articles/lulcheberet/Kitis-po..

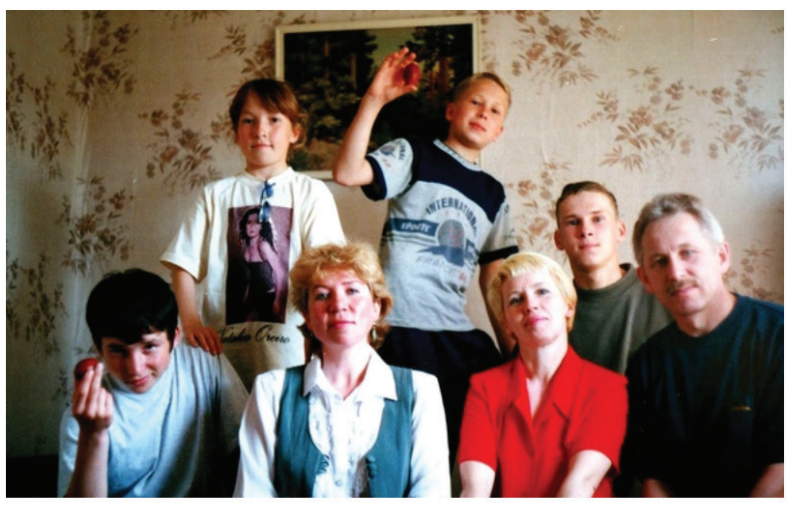

Example 17. Source: $h t t p s: / / v k . c o m /$ feed? $w=w a l l 135609259 \_99037$, last accessed on 1 December 2020. 
Новотатышлинская-Сельская Модельная-Библиотека-

Татышлински

19 апр в 20:30

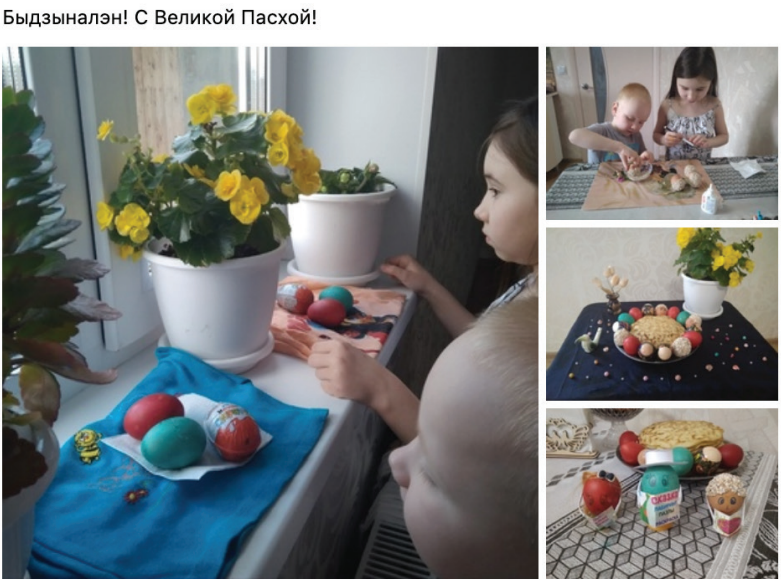

Example 18. Source: https: / / vk.com / feed?w=wall262345748_1048, last accessed on 1 December 2020.

\section{Explanatory notes}

During this period, it was also possible to notice posts in social networks explaining, for instance, what to do during this or that holiday, what actions to perform or, on the contrary, what is prohibited, or what dishes to cook. For example, the Udmurt sacrificial priest Anatoly Galikhanov in his Vkontakte post described the traditional celebration of Bydzh'ynnal. He wrote that during this holiday at first the guests were invited by the relatives living in the part of the village located at the lower reaches of the river, ${ }^{15}$ during Bydzh'ynnal kel'yan ('taking leave of the Great Day') they were already visiting relatives whose house was located at the upper reaches of the river; the indispensable dish of these rites was porridge with goose meat. It is also noted that during the commemoration, relatives whose house was on the upper reaches of the river were invited to come over and eat soup, and then the houses of others on the lower reaches of the river were visited. On the Vkontakte social network, the district newspaper of the Kukmor District of Tatarstan Vamysh ('Step') posted a photograph of colored eggs with a short message about the actions that are performed during the Bydzh'ymnal and Akashka festivals. Liliya Garaeva, a connoisseur of Udmurt traditions and the wife of the sacrificial priest of Aribashevo village in the Tatyshly District of Bashkortostan, published an article under the heading "Vös' ortch'yton esep"yos" ('Rules of prayer') in the public-political, social, cultural, and educational newspaper of the Bashkortostan Udmurts Oshmes 
('Source'), in which she wrote about the prohibition against the participation of a large number of people in the traditional summer prayers of the Eastern Udmurts, and appealed to the readers, explaining the importance of following the rules of behavior at the ceremony and the "dress code" during the ritual (Garaeva 2020: 2).

Example 19. Source: ht $t \mathrm{ps}: / \mathrm{l}$ k. co $\mathrm{m} /$ feed? $w=$ wall82757120_1445, last accessed on 1 December 2020

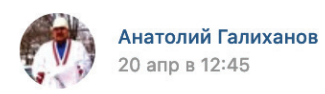

Азьло, Бдӟыналэ, пересьёс вань дыря, кужмазы дыря ӧтчаськиськом вал. Нырысь ӧтё шурлэн уллань палаз улись туганъёс, собере Быдӟынал келяку шурлен выллапалаз улись дорын кунояло вал. Обезательно ӟазег силен жук сиём вал. Али вань на меда сыӵеос? кылэм ӧвӧл. Нош кисььон дыря пӧсь шыд сиыны ӧтчаськоно вылланисен уллане.

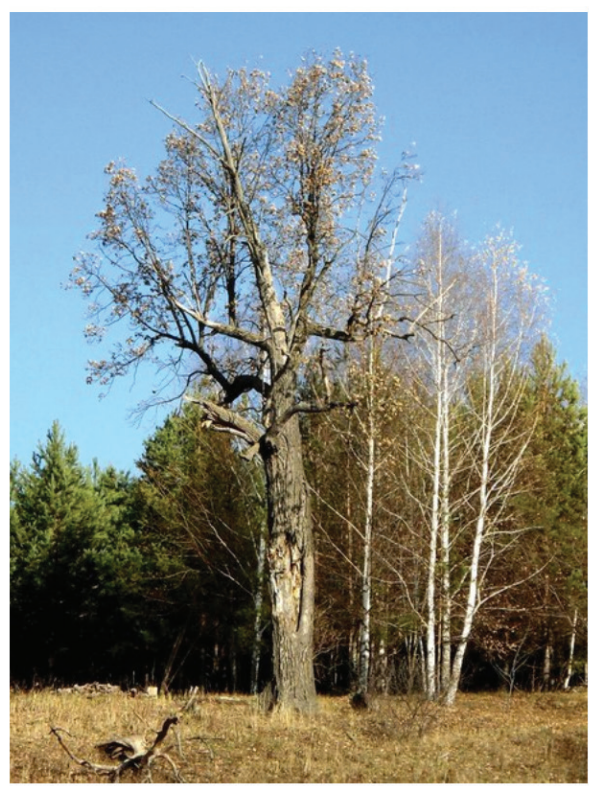

Example 20 (below). Source: https://vk.com/ vamysh_kukmor? $w=$ wall-108797331_3361, last accessed on 1 December 2020.

Быдзымнал, Акашка (Пасха)

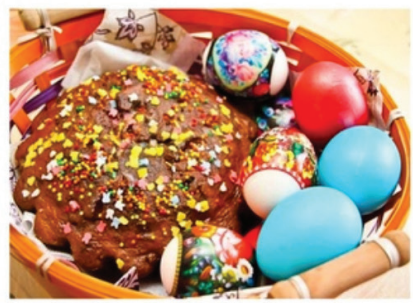

Начало нового земледельческого цикла сопровождалось обрядами

изгнания Шайтана, чтобы не испортил праздника. В этот день красили яйца и складывали их в лукошко вместе с зерном. Эти яйца вместе с зерном разбрасывали по полю и просили у бога хорошего урожая, зерен величиной с яйцо. 


\section{COVID-19 AND THE TRADITIONAL SUMMER PRAYERS OF THE EASTERN UDMURTS}

The Eastern Udmurts are a special ethnographic group of peripheral Udmurts, who avoided Christianization and have practiced their religion to this day. This year, the traditional summer prayers of the Eastern Udmurts were held in special conditions. For instance, in the Tatyshly District of Bashkortostan, during the quarantine period, the population discussed the possibility of broadcasting ceremonies online via the Internet, as was organized for the services in Orthodox churches or, for example, for the traditional ceremonies of the Mari (Agavairem-online 2020). However, broadcasts of Udmurt ceremonies did not take place. In the same district, in the ritual group of Novye Tatyshly (Udm. Vil'gurt $)^{16}$, the council of sacrificial priests and elders preliminarily discussed the conditions for holding ceremonies with the head of the Novye Tatyshly Village Council. The head gave instructions to the participants of the ceremony to wear protective masks and take precautionary measures. The organizers of the ceremony were informed that during the ceremony there may be an inspection. It was planned that only priests and a few helpers would participate in the ritual event, Gurt/-en vös' ('village ceremony') would be held, but there would not be a collective ceremony with the participation of several district villages - Mör vös' ('district ceremony') (Baidullina 2020). Further, based on the data from the Internet and online interviews, we will briefly consider the characteristics of the ceremonies of the Eastern Udmurts in COVID-19 conditions.

In Urazgil'dy village of the Tatyshly District of Bashkortostan, Gurt/-en vös' (village ceremony) was held on Thursday, June 4, although ceremonies are traditionally performed on Fridays. The informants felt that the ceremony should be held before the full moon, that is, on Thursday, because the full moon coincided with Friday. Two days before the prayer, specially appointed people (nine women) collected money for the ceremony vös' dun and grain for porridge from the villagers, but with the mandatory "dress code" of protective masks and gloves (Fig. 1). The day before the ceremony, the holy place was cleaned and prepared for the upcoming ritual. The ritual itself began on Thursday, at $8 \mathrm{am}$. This year, the prayer was attended by a sacrificial priest kuris'kis', male helpers, and some female helpers who had the task of cleaning the entrails of the sacrificial animal. The overseer of the holy place vös' kuz'o distributed protective masks for the ceremony participants. In their prayers, both the priest and the ceremony participants also asked for protection from the dangerous disease that had taken over the world. After the end of the prayer, several participants were treated to kumyshka (moonshine) behind the fence of the holy place. Other villagers were forbidden to participate in the ceremony at the 
sacred place. They received their portion of consecrated porridge only in the evening after the ceremony, after $4 \mathrm{pm}$. On the evening of the same day, each family gathered at the same table and tasted the consecrated porridge with a prayer addressed to the gods (oral message, anonymous, 2020).

In Malaya Balzuga village in the Tatyshly District of Bashkortostan, also only a sacrificial priest and a few helpers participated in the Gurt/-en vös' prayer. While in the past years the grain for the ceremony was collected by children, this year the grain and money vös' dun for the ceremony were collected by seven adult helpers. The ceremony itself was held on Friday. Unlike the previous example, the local priest listened to the advice of Liliya Garayeva from Aribashevo, a connoisseur of Udmurt traditions, who referred to the fact that the full moon began only on Friday evening and lasted until Saturday. The same example was followed by the priests of Novye Tatyshly, who held a ceremony on Friday. Afterwards, the consecrated porridge was brought to the village, and seven helpers distributed it to the villagers. In previous years, people received the ritual dish directly at the sacred place (oral message, anonymous, 2020).

In Asavka village in the neighboring Baltachevo District of Bashkiria, almost all the traditional summer ceremonies - Gurt/-en vös' and Mör vös' - were held.

Figure 1. Collecting grain and money vös' dun for the ceremony. Urazgil'dy, Tatyshly District, Bashkiria. Photograph by Anna Baidullina, June 2, 2020 .

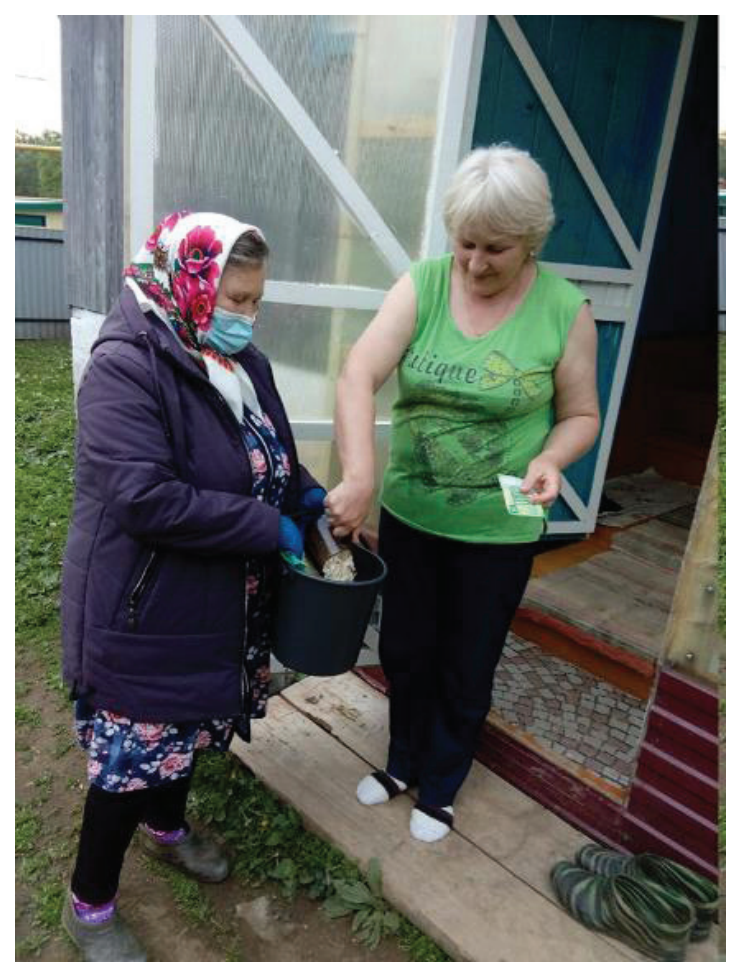




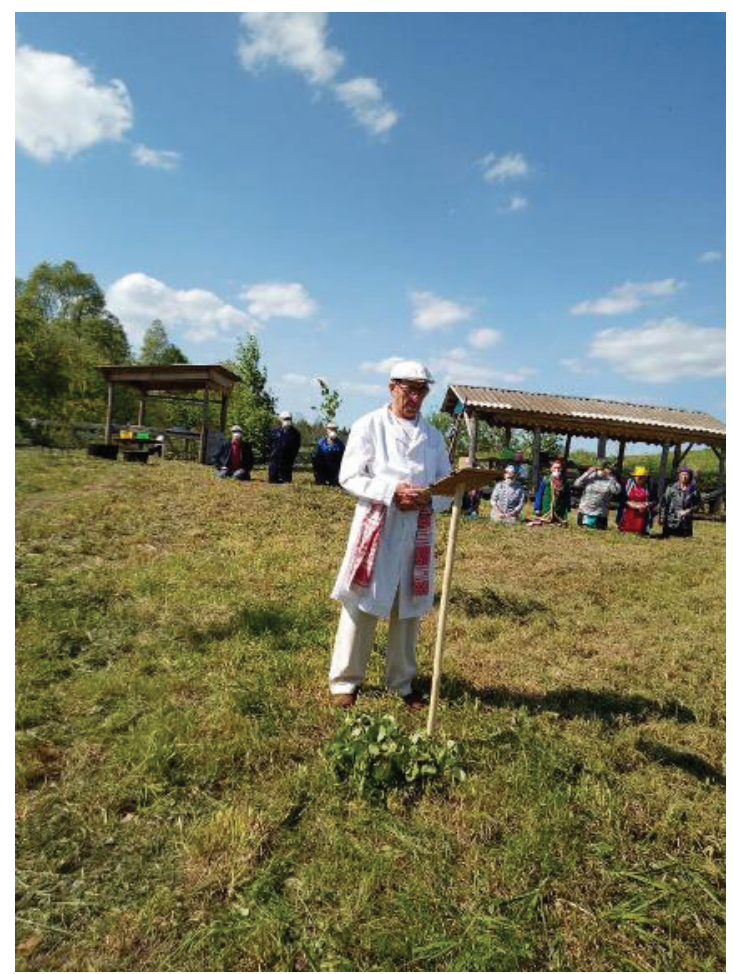

Figure 2. Prayer address by priest Ralif Garayev. Urazgil'dy village, Tatyshly District, Bashkiria. Photograph by Anna Baidullina, June 4, 2020.

Figure 3 (below). Participants of the Gurt/-en vös' ceremony. Urazgil'dy, Tatyshly District, Bashkiria. Photograph byAnnaBaidullina, June 4,2020.

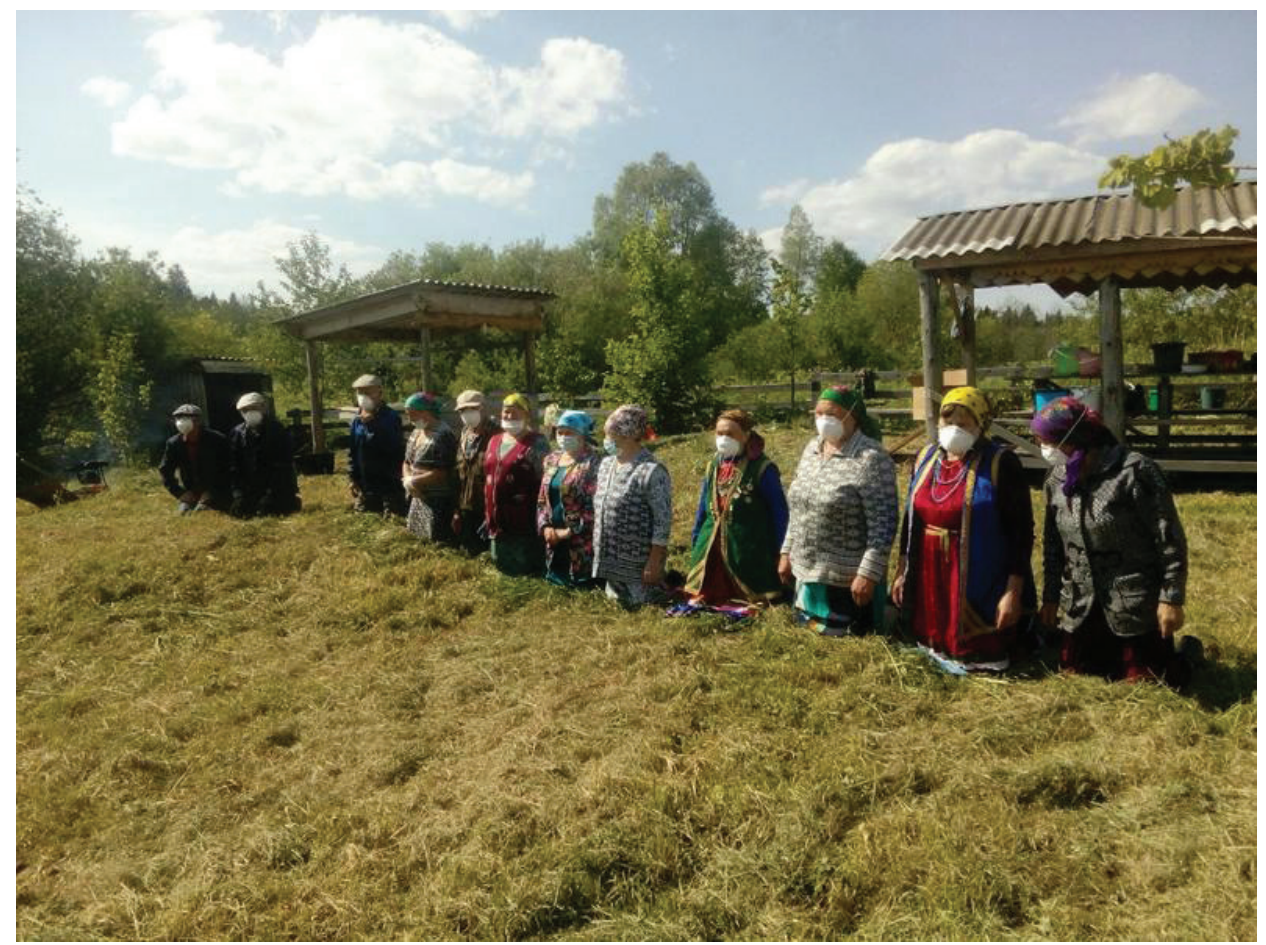


Figure 4. Participants in the prayer in Asavka village, Baltachevo District, Bashkiria. Photograph by Victoria Kiryanova 2020.

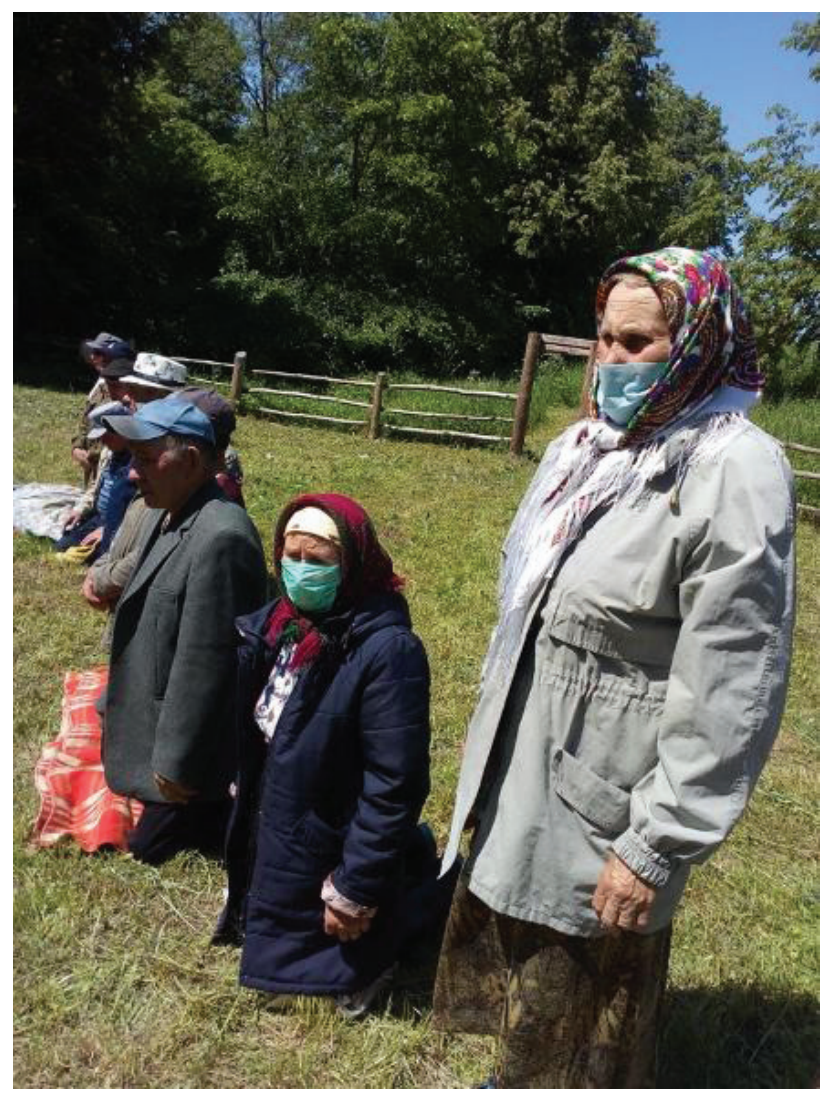

According to the sacrificial priest, this year they could not hold a ceremony in honor of Mukylchin, the deity of the land, because the village did not have a suitable sacrifice - a black ram/sheep. According to the village priest, before the ceremonies he called the priests of the Tatyshly District and consulted with them on how they had planned to hold the ceremonies in the current conditions. In the end, he decided to hold all the ceremonies, but with the use of personal protective equipment and disinfection (masks, gloves, alcohol solution). The ritual was attended only by those villagers who expressed their desire, mostly elderly people. It is curious that the Tatars living in this village supported the ceremonies of the Udmurt by donating money. This year, several Tatar families donated money in denominations of fifty and one hundred rubles. In his prayer, in addition to obligatory requests, the priest asked for assistance in protection against diseases, referring to this year's pandemic. Together with two elders, he prayed on his knees and consecrated the porridge, which was then distributed to all present. The priest noted that upon the declaration of 
quarantine on the streets of the village, a local police officer drove around in a car and announced to the local residents through a loudspeaker that it was forbidden for elderly people to walk on the street. After the Gurt/-en vös', a small informational article was published in the Udmurt-language newspaper of the Bashkortostan Udmurt, Oshmes ('Source'), with the title "Vös'as'kemzy kabyl med luoz" ('Let their prayers be heard/accepted [by God]') (Kiryanova 2020). The article describes the specifics of the ceremony, emphasizes the small number of participants, and expresses the hope that, despite the current situation, Inmar-Kylchin will hear/accept the prayers of the villagers (ibid.).

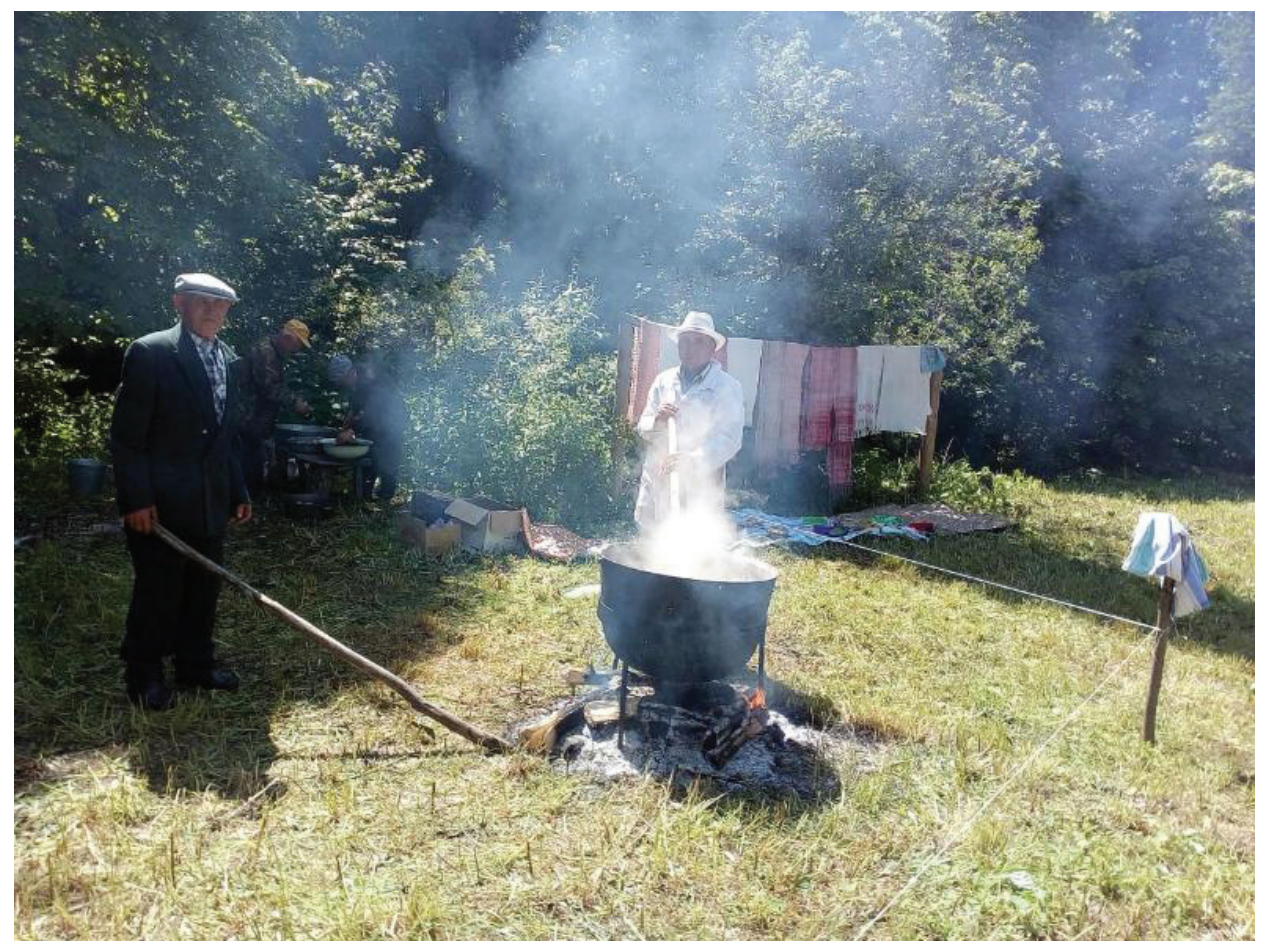

Figure 5. Cooking the ritual porridge. Asavka village, Baltachevo District, Bashkiria. Photograph by Victoria Kiryanova 2020. 


\section{SONGS AND CHASTUSHKAS ABOUT THE CORONAVIRUS AND SELF-ISOLATION}

During this period, a curious phenomenon appeared in Udmurt culture. People began to compose songs and chastushkas dedicated to the theme of coronavirus and self-isolation. It is known that in the folklore of any people humorous songs and chastushkas (ditties) belong to the lyrical kind of poetry, so their main purpose is not to describe events, but express and transmit feelings, thoughts, and moods. As a rule, the messages reveal that the lyrics of songs come from the performer, and music can be both a folk tune or the performer's. It should be noted that writing musical texts on this topic has gained a wide scale (see, e.g., Chastushkas from Kuzmich 2020; Chastushkas about coronavirus 2020; Competition 2020; Italian 2020; Music video 2020; Kakha video 2020). Interesting examples were also found in the modern culture of the Udmurts. Here are the lyrics of the songs at our disposal, most of which are based on humor.

\section{Example 1.}

Везде кипишь, везде шок, Киттокын но тоже шок.

Та вирусэз маин виёд, Pецептсэ кьıтьсь шедьтод?

Та вирусэз маин виёд, Pецептсэ кымыьсь шедьтод?

Уралие потса учки вал, Огкин но ӧвӧл, пайлод! Доре прыса киме миськи, Курыт вуэн чушиськи. Доре прыса киме миськи, Курьљт вуэн чушиськи.

Сиса адӟел вал чеснок, Зьнньз потэ, ой, чоньдод! Собере нош курыт вуэн Чьютыьлие гылтӥ кык пол. Собере нош курыт вуэн Чыртылле гылтӥ кык пол.

Кыьтын чыртыь, отыцн гылён, Кошкиз, кошкиз гань-гань!
Everywhere turmoil, everyone in shock, And so is China, too, in shock.

How to kill this virus,

Where to find the scheme?

How to kill this virus,

Where to find the scheme?

I went outside to look,

There is no one, what a surprise!

I got home, washed my hands, And wiped myself with alcohol.

I got home, washed my hands,

And wiped myself with alcohol.

I tried eating garlic,

The smell is, oh, you'll perish!

Then again with alcohol I

Gargled twice.

Then again with alcohol I

Gargled twice.

Where's a neck, there's a throat, It's going, going smoothly! 
Вот табере мон валай,

Now I understand,

Айбат “дару” принилай!

Take good "medicine"!

Вот табере мон валай, Now I understand,

Айбат “дару” принилай!

Take good "medicine"!

(Performer anonymous, Bashkortostan 2020)

\section{Example 2.}

Ужтэллэсь уж луоз али -

Вина пӧзьтыныь пуктӥ.

Ужтэллэсь уж луоз али -

Вина пӧзьтыцны пуктӥ.

Гажано туган-ешьёсьн

Юны лед гожтоз али.

Гажано туган-ешъёсын

Юны мед гожтоз али.

Ай, три-дари та-тал,

Вай, три-дари та-тали.

Ай, три-дари та-тал,

Вай, три-дари та-тал.

“Короновирус" шуыса

Дорьёсаль пукиськол.

“Короновирус" шуыса

Доргёсаль пукиськом.

Оскисько чергёс ортчьса,

Жоген чошен пулиськол.

Оскисько черьёс ортчьса,

Жоген чошен пулиськол.

Ай, три-дари та-тал,

Вай, три-дари та-тали.

Ай, три-дари та-тал,

Вай, три-дари та-тал.

Тазальљ, шудбур сӥзьыса, Чаркалес шуккол али.

Тазальљ, шудбур сӥзьыса, Чаркалес шуккол али.

Пукол удлурт гур кисьтыса,
Idling will become working -

I started to cook kumyshka.

Idling will become working -

I started to cook kumyshka.

With dear relatives and friends

Let it be fated to celebrate.

With dear relatives and friends

Let it be fated to celebrate.

Ay, tri-dari ta-tam,

Wai, tri-dari ta-tam.

Ay, tri-dari ta-tam,

Wai, tri-dari ta-tam.

Saying "Coronavirus"

We are sitting in our homes.

Saying "Coronavirus"

We are sitting in our homes.

I believe when the disease passes

We'll meet again soon.

I believe when the disease passes

We'll meet again soon.

Ay, tri-dari ta-tam,

Wai, tri-dari ta-tam.

Ay, tri-dari ta-tam,

Wai, tri-dari ta-tam.

Wishing health and happiness

Let's clink our cups.

Wishing health and happiness

Let's clink our cups.

Udmurt melody performing, we'll sit, 
Эктысса но шудыıса.

Пукол удмурт гур кисьтьса, Эктыска но шудыєса.

Ай, три-дари та-тал, Вай, три-дари та-тали.

Ай, три-дари та-тал,

Вай, три-дари та-тал.

Oй, эсьласа, эсьласа,

Сӥзььил палэзь кисьмаса.

Oй, эсьласа, эсьласа,

Сӥзьыл палэзь кисьмаса.

Льєттәлэ вал тӥ, ешъёсь,

Чошен юол эсьласа.

Льєктэлә вал тӥ, ешъёсь,

Чошен юол эсьласа.

Ай, три-дари та-тал, Вай, три-дари та-тал.

Ай, три-дари та-тал, Вай, три-дари та-тали.

Льюттллэ вал тӥ, ешъёсь,

Чошен юол эсьласа.

Льєктэлә вал тӥ, ешъёсь,

Чошен юол эсьласа.

Короновирусэз ворльса!
Dancing and playing.

Udmurt melody performing, we'll sit Dancing and playing.

Ay, tri-dari ta-tam, Wai, tri-dari ta-tam. Ay, tri-dari ta-tam, Wai, tri-dari ta-tam.

Oh, so yes, at least

With ripening rowanberries in the fall it would be.

Oh, so yes, at least

With ripening rowanberries in the fall it would be.

Would you come, friends,

We'd celebrate together.

Would you come, friends,

We'd celebrate together.

Ay, tri-dari ta-tam,

Wai, tri-dari ta-tam.

Ay, tri-dari ta-tam,

Wai, tri-dari ta-tam.

Would you come, friends,

We'd celebrate together.

Would you come, friends,

We'd celebrate together.

Defeating the coronavirus!

(Performer Minliaskarova Irina, born in 1959. Starokalmiyarovo village, Tatyshly District, Bashkortostan, 2020)

\section{Example 3.}

Мар пукиськод али дорад?

Мар карьєса кьллиськод?

“Коронавирус" шуысса,

“Коронавирус" шуыса,

Пулиськьчтэк кьлллиськол.
Why are you staying at home?

What are you doing?

Saying "Coronavirus"

Saying "Coronavirus"

We live without meeting. 
Мон азбаре потай али, Well, I went out into the yard, Юрт котырез тазартыны. To clean around the house.

Мон азбаре потай али, Well, I went out into the yard, Юрт котырез тазартыныь. To clean around the house.

Курег басьтыса шашльюк лэсьтӥ, I bought chicken, soaked shashlik, Настроениез жутыны. [To] cheer up.

Курег басьтыса шашлык лэсьтӥ, I bought chicken, soaked shashlik, Настроениез жутыны. [To] cheer up.

(Anonymous, town of Chernushka, Perm region, 2020)

\section{Example 4.}

Вирус вуэм Алнаше!

Вирус вуэл Алнаше,

Калык уральıсь ыцше.

Ветло уралтӥ “эшъёс",

Ваньзэс улляло соос.

Вася бертыны потэл, Алнаш пала ни вуэл, Дугдыттэл сое патруль, Поворачивай, пе, руль. "Едь туда, откуда сам", Но пырон сюрес ворсал. “Как же так?" - шуэ Васи, “Я же местный Ӟатча пи”.

“Как же так?" - шуэ Васи, "Я же местный Ӟатча пи. Лэзе тӥ монэ гуртам, Сю манет за это дал". "Уксёдэ тон ват бордад, Со уксен ветль в продмаг, Ну, а маска ке кузьлад, Может, ми лэзём гуртад”. Василэн синльз долказ, Дас маска бардачоказ, "Мелэ, ваньзә сётӥсько, Тӥледль мон оскисько”.
The virus has reached Alnashi!

The virus has reached Alnashi, There were no more people on the streets. "Friends" are walking down the street, and making everyone turn away. Vasya left for home, and has already arrived at Alnashi, A patrol stopped him, Said to turn the steering wheel. "Go where you came from," And blocked the road. "How so?" - says Vasya, "I'm a local guy from Varzi-Yatchi."

"How so?" - says Vasya, "I'm a local guy from Varzi-Yatchi.

Let me go home, I'll give you a hundred rubles for this."

"Keep your money, With this money go to the grocery store, Well, if you give us a mask, Maybe we'll let [you] go home." Vasya stares surprised, There are ten masks in his glovebox, "Take it, I'll give you everything, I trust you." 
Баш на баш ужа Алнаш,

Васи тот ещё торгаш,

Со тодэ таре секрет,

Кьӥе иенится манет.

Со тодэ таре секрет,

Кьӥе ценится манет.

Кьљзыы можно бертыьны,

Алнаше но пырыны.

Алнаше но пырыны.
Alnashi works tit for tat, Vasya is such a tradesman, Now he knows the secret, How the ruble is valued.

Now he knows the secret, How the ruble is valued. How he can go home, And stop by Alnashi.

And stop by Alnashi.

(Once again 2020)

The following example is related to the Ektonika (from the noun ekton 'a dance, hopping') project initiative as presented by Vladislav Gorzhak. One of the project's participants, a young poet Bogdan Anfinogenov, wrote the Udmurt-Russian text, and Vladislav Gorzhak composed an arrangement based on a wedding melody of the Western (Trans-Vyatka) Udmurts. The result was the recording of a song and shooting of a video for the song "Kosh tatys', koronavirus" ('Get out of here, coronavirus') with the participation of people famous in Udmurtia and all those wishing to take part in the action (Ektonika 2020). The video was marked with the hashtags \#ЛучшеДола, \#ДорынУмойгес (better at home), \#ОставайтесьДома (stay at home), \#КоронаВирус (Coronavirus), \#МояУдмуртия (My Udmurtia ${ }^{17}$ ), \#КьљлзэДорыьн (listen at home), \#StayatHome, \#Удмурты (Udmurts), \#Удмуртия (Udmurtia).

\section{Example 5.}

Я сижу на карантине,

Я сижу на карантине,

Убираться нет уж сильь,

Нет уж сильь!

Укно миськи, выж но миськи, I washed the window and the floors,

Оти миськи, тати миськи, I washed it there, I washed it here,

Нош ик куать час бере сиськи, I ate again after six o'clock,

Куать час бере!

Астэ ачид нимаз висдян, Астэ ачид нимаз висәян,

Карантин та акыльтӥз ни, Карантин та!

Кош татысь, коронавирус,
I'm in quarantine,

I'm in quarantine,

I'm exhausted from tidying up,

I'm exhausted!

After six o'clock!

Self-isolation,

Self-isolation,

I'm tired of this quarantine,

This quarantine!

Get out of here, coronavirus, 
Kош татысь, коронавирус, Get out of here, coronavirus,

Эн ветль татӥ тон, изьвер! Don't walk here, you wild beast!

$Э$ Эн эн ветльь!

No, don't go!

Ой, тьл, порушка-пораня,

Oh, you, porushka-poranya,

Ой, ты, эктоника родная,

Oh, you, darling Ektonika,

Зачел я опять встал рано,

Why did I get up early again,

Очень рано!

Very early!

Я за то люблю диваньи,

I love sofas for that,

Ой, я за то люблю дивань,

Oh, I love sofas for that,

Поваляться с книжкой славно, It's nice to lie around with a book,

Можно славно!

It's nice!

Астэ ачид нимаз висъян,

Self-isolation,

Астэ ачид нилаз висьян,

Self-isolation,

Карантин та акьльтӥз ни,

Карантин та!

I'm tired of this quarantine,

This quarantine!

Кош татысь, коронавирус,

Get out of here, coronavirus,

Кош татысь, коронавирус,

Get out of here, coronavirus,

Эн ветль татӥ тон, изьвер!

Эн, эн ветльь!

Don't walk here, you wild beast!

No, don't go!

За продуктали я вышел,

I went out to get food,

Мусор выкинул не сльшно,

I threw out the garbage quietly,

А погодка прял по кайббу,

Пряли по кайббу!

And the weather is so-so nice,

Ку ини чорыгало мон,

Сиена выльн кырзало но,

Одно ик ворлол эшгёс ми,

Одно ворлол!

So-so nice!

When will I go fishing

And sing on stage again?

We will definitely win, friends,

Win!

Астэ ачид нилаз висъян,

Астэ ачид нимаз висъян,

Self-isolation,

Карантин та акыльтӥз ни,

Карантин та!

Self-isolation,

I'm tired of this quarantine,

This quarantine!

Кош татысь, коронавирус,

Get out of here, coronavirus,

Кош татьсь, коронавирус,

Get out of here, coronavirus,

Эн ветлы татӥ тон, изьвер!

Эн, эн ветльц!

Don't walk here, you beast!

No, don't go! 
Массовый движ избегаю, Массовый движ избегаю, На балконе занилаюсь, Я качаюсь!

На гармошке разминаюсь, На гитаре я лабаю, И чтобы не заразиться Распеваюсь!

Астэ ачид нилаз висдян, Астэ ачид нимаз висәян, Карантин та акыльтӥз ни, Карантин та!

Кош татысь, коронавирус, Кош татысь, коронавирус, Эн ветльь татӥ тон, изьвер! Эн, эн ветльь! $!^{18}$
I avoid mass events, I avoid mass events, On the balcony I take exercise, I pump iron!

I warm up on the harmonica, I play the guitar, And in order not to get infected, I sing!

Self-isolation, Self-isolation,

I'm tired of this quarantine, This quarantine!

Get out of here, coronavirus, Get out of here, coronavirus, Don't walk here, you wild beast! No, don't go!

The difference of this example from the previous ones is that this song has a didactic function, was widely promoted in the Internet space and is a pre-planned action. In the first four cases, the initiative was spontaneous and was not aimed at a widespread distribution but was rather a creative expression of a person's will. Recordings of these songs "from the people" are not always available in the public domain and are mainly sent only to one's friends and acquaintances via social networks or messengers. These recordings are later distributed through these friends further to others. The main theme is the fight against the virus and the description of life in self-isolation. These examples are a kind of reaction of society / creative individuals to extraordinary events taking place in the country and around the world. In this respect, musical language is a good way for people to express themselves and to relieve psychological tension. Because such songs contain plenty of humor, they evoke a smile or even laughter from the listener, which most likely also helps to relieve anxiety in the face of the pandemic. The same can be seen in various comments and a positive feedback from listeners, although there are those who disagree, saying: "Chto za shuzi kyrzan" ('What a stupid song') (Ektonika 2020). 


\section{CONCLUSIONS}

This study allowed us to briefly highlight the most striking aspects of the existence of traditional culture of the Udmurts under the quarantine and selfisolation declared in Russia in connection with COVID-19. These examples show various effects of COVID-19 on the traditional ritual culture of the Udmurt people. There are several factors that characterize the behavior of people in this situation: 1) following quarantine and performing rituals in the family circle or by a limited number of people; 2) activity on social networks through posts and discussion of photographs and videos showing the preparation for and the performance of rituals; 3 ) performing traditional rituals as usual in some rural areas. Apparently, it is not appropriate to talk about the villagers' disregard of the state decree. The action of local authorities played an important role: measures were taken in a timely manner to quarantine villages and cities in Udmurtia and nearby regions, so during the pandemic the coronavirus had little opportunity to spread in the villages. In this regard, the situation with COVID-19 likely did not cause much panic among the villagers. On the contrary, they performed their rites in a calm atmosphere.

Of special interest were chastushkas and songs that were composed during this period as a kind of creative reaction to the circumstances and as a way to relieve stress.

The prohibition of mass gatherings forced people to look for alternative ways of communication. This was the case with the Internet. In the virtual space, there is an opportunity to share life in the pandemic context with friends, relatives, and the world. It should be noted that the Internet has become a valuable source not only of the behavior and occupations of the population in the conditions of self-isolation, but also of the study of the current state of traditions and their existence in a crisis situation.

In addition, the materials above showed the importance of emotional communication between people and the need for spiritual unity in the moments of celebration of rites and festivals. Despite the various options offered instead of ritual ceremonies, people could not fully feel and receive those feelings, and therefore expressed their frustration and bitterness. At the same time, according to Internet posts, the Udmurts tried to support each other in this difficult life situation. The lyrics of songs are a good example of this.

Today it is difficult to talk about the serious impact of the coronavirus on the traditional culture of the Udmurts. Doing so will take time and require further observation. However, this study is valuable because it has recorded information, facts, and phenomena from this period as well as people's comments on this issue. In the future, such information will allow us to trace the subsequent possible changes caused by COVID-19 in Udmurt culture. 


\section{ACKNOWLEDGEMENTS}

The article was supported by the research grant of the Estonian Literary Museum EKM 8-2/20/3 and by the Centre of Excellence in Estonian Studies (TK 145) through the European Regional Development Fund.

\section{NOTES}

1 The name of the festival is used in different forms in different regions of Udmurtia.

${ }^{2}$ Currently, these holidays are timed to coincide with Orthodox Easter. Usually, Akashka is held on the eve of Easter, and Bydzh'yn nunal is seen as Easter, so it is celebrated on Sunday, Easter Day. In 2020, Easter was celebrated on April 19.

${ }^{3}$ The bölyak is a smaller kin group consisting of some families in the patrilinear line.

${ }^{4}$ Prayerful address similar to the Russian "Oh, Lord!".

5 Theonym of the supreme celestial god in the Udmurt pantheon.

${ }^{6}$ See https://vk.com/alnashiclub145006838?w=wall-145006838_2653, last accessed on 1 December 2020.

7 The agrarian festival of the end of spring field work.

${ }^{8}$ Source: https://instagram.com/ymia_library?igshid=torhnvtvvzlv, no more available.

9 Source: https://vk.com/feed?w=wall251706873_893, last accessed on 1 December 2020.

${ }^{10}$ Source: https://vk.com/feed?w=wall10544255_2116, last accessed on 1 December 2020.

${ }^{11} \mathrm{~A}$ variety of pancakes made of sour yeast dough.

${ }^{12}$ Source:https://vk.com/id82757120?w=wall82757120_1447, lastaccessed on 1 December 2020.

${ }^{13}$ Source: https://vk.com/id82757120?w=wall82757120_1440, lastaccessed on 1 December 2020.

${ }^{14}$ Kylchin = 'angel'. An ordinary way to address God.

${ }^{15}$ The fact is that in the Udmurt tradition, it is still strictly observed from which end of the village, from the house of which relative, to start visiting yards. The ritual visits of houses on calendar holidays (vös'nerge) began at the head of the river or upstream (Shur vyllan' vetlyny, 'to go/walk to the head of the [river] upstream'); the ritual visits of houses during the memorial days (kis'ton) began downstream (Shur ullan'vetlyny, 'to walk/go to the lower [river] downstream') (Vladykina \& Glukhova 2011: 146).

${ }^{16}$ In the Tatyshly District, researchers have identified two ritual groups. Each group has its own traditions and features of holding prayers, but together they form a single, well-functioning system. The Novye Tatyshly (Vil'gurt) group got its name from the ritual center in the village of Novye Tatyshly (for more details see Toulouze \& Niglas 2014: 111).

${ }^{17}$ A radio and television channel in the Udmurt language.

${ }^{18}$ The text provided by Vladislav Gorzhak is given with the original punctuation and spelling preserved. 


\section{REFERENCES}

Agavairem-online 2020 = Agavairem-onlain: vpervye proidet priamaia transliatsiia mariiskikh molenii. [Agavayrem-online: Live Broadcast of Mari Prayers Will Be Held for the First Time.] Vk.com. Available at https://vk.com/doc30306561_55 7262847?hash=af4d0d758730cbcff3\&dl=4a6423a5ab649f2a58, last accessed on 30 November 2020.

Amelina, Mariia 2020. Pokhorony vo vremia pandemii: Kak v Minske khoroniat patsientov s COVID-19. [Funeral during a Pandemic: How Patients with COVID-19 Are Buried in Minsk.] Sputnik.by, 30 April. Available at https://sptnkne.ws/Cnpk, last accessed on 30 November 2020.

Baidullina, Anna 2020. Gurten vös'es ortcho. [The Village Ceremonies Take Place.]. Oshmes. rbsmi.ru, 4 June. Available at https://oshmes.rbsmi.ru/articles/oskon/Gurtenv-syos-ortcho-304791/?sphrase_id=6112, last accessed on 30 November 2020.

Chastushkas from Kuzmich $2020=$ Chastushki ot Kuz'micha. Pro koronavirus. [Chastushkas from Kuzmich. About Coronavirus.] Vk.com. Available at https://vk.com/ im?peers $=455362247 \&$ sel $=220510108 \& \mathrm{z}=$ video301522471_456239075\%2F7a57 c63fe22b4cdb97\%2Fpl_post_301522471_46, last accessed on 30 November 2020.

Chastushkas about coronavirus $2020=$ Chastushki pro koroavirus. Vk.com. Available at https://vk.com/video?q=\%D1\%87\%D0\%B0\%D1\%81\%D1\%82\%D1\%83\%D1\%88\%D 0\%BA\%D0\%B8\%20\%D0\%BF\%D1\%80\%D0\%BE\&z=video32627244_456242727, last accessed on 30 November 2020.

Competition 2020 = Chastushki na temu samoizoliatsiia. [Chastushkas about Selfisolation.] Vk.com, 19 May. Available at https://vk.com/video?q=\%D1\%87\%D0\% B0\%D1\%81\%D1\%82\%D1\%83\%D1\%88\%D0\%BA\%D0\%B8\%20\%D0\%BF\%D1\%80 $\% \mathrm{D} 0 \% \mathrm{BE} \& \mathrm{z}=$ video-194634011_456239404, last accessed on 30 November 2020.

Coronavirus 2020 = Koronavirus skazyvaetsia na traditsionnoi kul'ture v Iaponii. [Coronavirus Affects Traditional Culture in Japan.] Nippon.com, 5 March. Available at https://www.nippon.com/ru/news/yjj2020030400535/, last accessed on 30 November 2020.

Ektonika 2020 = Ektonika - Brys' otsiuda, koronavirus (Kosh tatys', koronavirus). [Ectonica - Get Lost, Coronavirus.] Youtube.com, 17 May. Available at https:// youtu.be/wCzlFvjGubk, last accessed on 2 December 2020.

Garaeva, Liliia 2020. Vös' ortchyton esep"es. [The Rules for Holding a Ceremony.] Oshmes, No. 23 (1092), p. 2.

Hine, Christine 2000. Virtual Ethnography. London \& Thousand Oaks \& New Delhi: SAGE.

Italian 2020 = Ital'ianets sochinil ukrainskuiu chastushku pro koronavirus. [An Italian Composed a Ukrainian Ditty about Coronavirus.] Vk.com, 4 April. Available at https://vk.com/video?q=\%D1\%87\%D0\%B0\%D1\%81\%D1\%82\%D1\%83\%D1\%88\%D 0\%BA\%D0\%B8\%20\%D0\%BF\%D1\%80\%D0\%BE\&z=video-59719760_456240760, last accessed on 30 November 2020.

Japanese 2020 = Iapontsy iz-za koronavirusa perestali vmeste pit' chai i sake. [Japanese People Stop Drinking Tea and Sake Together due to Coronavirus.] Rossaprimavera. ru, 4 March. Available at https://rossaprimavera.ru/news/7a8f9956, last accessed on 2 December 2020. 
Kakha video 2020 = Sergo i Kakha klip 2020 koronavirus pesnia. [Sergo and Kakha Clip 2020 Coronavirus Song.] Youtube.com, 25 April. Available at https://www.youtube. com/watch?v=_S7xv6X_cPk\&feature=youtu.be, last accessed on 30 November 2020.

Kiryanova 2020 = Kir'ianova, Viktoriia. Vösias'kemzy kabyl med luoz. [Let Our Prayers Be Accepted.] Oshmes, No. 24 (1093), p. 2.

Korovina, Agata 2020. Kak na Altae pytaiutsia dogovorit'sia s dukhom COVID-19 i spasti planetu. Interv'iu s antropologom. [How Altai is Trying to Negotiate with the Spirit of COVID-19 and Save the Planet. Interview with an Anthropologist.] Knife.media, 10 May. Available at https://knife.media/altai-covid/, last accessed on 30 November 2020.

Kulichenko, Irina 2020. Tserkov' perenesla pominal'nye dni. [Church Postponed Memorial Days.] Izvestia.kharkov.ua, 22 April. Available at http://izvestia.kharkov.ua/ on-line/20/1303447.html, last accessed on 30 November 2020.

Kuznetsova, Irina 2020. Traditions and Technologies: A Change in the Practice of Orthodox Worship During COVID-Pandemic: The Case of the St. Elias Church of Krasnodar. The 7th Lumen Conference Nashs 2020, June 25-26. Online conference. Available at https://youtu.be/eHOmzuwSumY, last accessed on 27 January 2021.

Manichkin, Nestor 2020. Epidemicheskie ogranicheniia i opyt religioznoi obshchiny: tserkovnaia zhizn' moskovskikh katolikov vo vremia pandemii covid-19. [Epidemic Restrictions and the Experience of the Religious Community: Church Life of Moscow Catholics during the COVID-19 Pandemic.] Meditsinskaia antropologiia $i$ bioetika, 15 April. Available at http://www.medanthro.ru/?page_id=4540, last accessed on 2 December 2020.

Markham, Annette N. 2004 [1997]. Internet Communication as a Tool for Qualitative Research. In: D. Silverman (ed.) Qualitative Research: Theory, Method, and Practices. 2nd ed. London: SAGE, pp. 95-124. Available at https://annettemarkham. com/writing/silvermangalleyproofs.pdf, last accessed on 2 December 2020.

Music video 2020 = Muusikavideo "Für Koroona". [Nonofficial Music Video.] Youtube. com, 24 March. Available at https://youtu.be/udZ7m1dumSc, last accessed on 30 November 2020.

Once again 2020 = Eshche raz pro karantin. Ispolnitel' i avtor muzyki Aleksandr Galeev, avtor slov anonym. [Once Again about the Quarantine. Performer and Author of Music Alexander Galeev, Author of Words Anonymous.] Vk.com, 22 April. Available at https://vk.com/im?peers $=484005534 \&$ sel $=332254689 \& \mathrm{w}=$ wall145006838_2469\%2F1379bf402dd1d1f43d, last accessed on 30 November 2020.

Prange, Astrid \& Zhukov, Evgenii 2020. Pokhorony v usloviiakh pandemii koronavirusa: proshchanie zapreshcheno? [Funeral Amid the Coronavirus Pandemic: Farewell is Prohibited?] DW.com, 12 April. Available at https://p.dw.com/p/3akZy, last accessed on 30 November 2020.

Radchenko, Daria 2020. Easter Online: Producing Spaces, Transgressing Borders. The 7th Lumen Conference Nashs 2020, June 25-26. Online conference. Available at https://youtu.be/NZknhWPkAcQ, last accessed on 30 November 2020.

Sergeyeva, Ol'ga V. 2010. Mir sotsial'nykh setei: opyt virtual'noi etnografii na materiale VKontakte.Ru. [The World of Social Networks: The Experience of Virtual Ethnography Based on the Material of VKontakte.ru.] Nauka televideniia, No. 7. Available at https://cyberleninka.ru/article/n/mir-sotsialnyh-setey-opytvirtualnoy-etnografii-na-materiale-vkontakte-ru, last accessed on 2 December 2020. 
Soldatov, Aleksandr 2020. "Pir very" vo vremia chumy: Kak proshla karantinnaia Paskha. ["Feast of Faith" during the Plague: What Was the Easter Quarantine Like.] Novayagazeta.ru, 19 April. Available at https://novayagazeta.ru/ articles/2020/04/19/84990-pir-very-vo-vremya-chumy, last accessed on 30 November 2020.

Toulouze, Eva \& Anisimov, Nikolai 2018. “The Year Replaces the Year.” Udmurt Spring Ceremonies among the Non-Christian Udmurt: An Ethnographic Analysis of Contemporary Ritual Life (on Materials from Varkled-Böd'ya Village). Journal of Ethnology and Folkloristics, Vol. 12, No. 1, pp. 59-94. https://doi.org/10.2478/ jef-2018-0005.

Toulouze, Eva \& Niglas, Liivo 2014. Udmurt Animistic Ceremonies in Bashkortostan: Fieldwork Ethnography. Journal of Ethnology and Folkloristics, Vol. 8, No. 1, pp. 111-120. Available at https://www.jef.ee/index.php/journal/article/view/176, last accessed on 2 December 2020.

Traditional medicine 2020 = Traditsionnaia meditsina i COVID-19: chto dumaet VOZ? [Traditional Medicine and COVID-19: What Does the WHO Think?] News.un.org, 4 May. Available at https://news.un.org/ru/story/2020/05/1377352, last accessed on 30 November 2020.

Vladykina, Tatiana \& Glukhova, Galina 2011. Ar-god-bergan: Obriady $i$ prazdniki udmurtskogo kalendaria. [Ar-god-bergan: Rites and Holidays of the Udmurt Calendar.] Izhevsk: Izd-vo Udmurtskogo universiteta.

Volodina, Tat'yana 2020. Pandemiia i aktualizatsiia arkhaicheskikh skhem preodoleniia krizisnoi situatsii. [Pandemic and Actualization of Archaic Schemes for Overcoming the Crisis Situation.] Pandemiya i aktualizatsiya arkhaicheskikh skhem preodoleniya krizisnoy situatsii. Meditsinskaia antropologiia i bioetika, 23 April. Available at http://www.medanthro.ru/?page_id=4559, last accessed on 2 December 2020.

Nikolai Anisimov ( $\mathrm{PhD}$ ) is researcher at the Department of Folkloristics at the Estonian Literary Museum, Estonia, and at the Department of Philological Studies at the Udmurt Institute for Research in History, Language and Literature (UdmFRC UB RAS), Izhevsk, Russia. His main field of interest is Udmurt traditional and contemporary culture, and more precisely, the living ancestors' cult by the Udmurt and their singing tradition.

nikolai.anisimov@folklore.ee

Galina Glukhova (Candidate of Philology) is an Udmurt folklorist. She is Associate Professor at the Institute of Udmurt Philology, Finno-Ugric Studies and Journalism and teaches Udmurt literature and folklore. Her main field of interest is related to the research on Udmurt and Finno-Ugric folklore, Udmurt traditional culture, and the interaction of Udmurt folklore and literature.

galant@udm.ru 